\title{
Kant and Tetens on the Unity of the Self
}

\section{Udo Thiel}

There can be no doubt that Johann Nikolaus Tetens (I736-I 807) was one of Kant's most important German philosophical contemporaries. His main work, the huge and wide-ranging two-volume Philosophische Versuche über die menschliche Natur und ihre Entwickelung (Philosophical Essays on Human Nature and its Development) of I777, comprising a total of more than I,600 pages in the original edition, made a significant impression on the philosophical scene in the late eighteenth century. ${ }^{\mathrm{I}}$ Although the work was criticised in relation to many points of detail and from a variety of perspectives, it was, on the whole, well received and reviewed extensively. ${ }^{2}$ Kant, too, was impressed. Kant was critical of the work's unsystematic nature and style, and of aspects of its general approach; nevertheless, he thought of Tetens as one of the leading philosophers of the day, identifying him as one of the few thinkers of the time whom he could reasonably expect not only to understand but also to be able and willing to pursue the kind of project that he himself had developed in the Critique of Pure Reason. Kant does not mention Tetens in any of his published writings, but he does in various letters and notes. There is, for example, a letter to Marcus Herz from 1778 , another letter to Herz from $\mathrm{I} 78 \mathrm{I}$ and a letter to Garve from 1783 , and there are Kant's marginal notes in his copy of Tetens's book and other Reflexionen referring to Tetens. ${ }^{3}$

I Johann Nikolaus Tetens, Philosophische Versuche über die menschliche Natur und ihre Entwickelung, 2 vols, edited with commentary by Udo Roth und Gideon Stiening. This work is cited here according to volume and page number in the original edition of 1777 , also given in the Roth and Stiening edition. Eric Watkins has translated selections from Versuche into English. See Watkins (ed. and transl.), Kant's 'Critique of Pure Reason': Background Source Materials, pp. 353-9I.

2 See Roth and Stiening, 'Zur Einführung', in Tetens's Versuche, pp. xx-xxi.

3 Kant's letters to Marcus Herz are from April I778 and May I78 I (Corr, I0:232, 270), and the letter to Garve is from 7 August I 783 (Corr, I0:34I). Kant made marginal notes on pp. I9 and I 3 I in vol. I of his copy of Tetens's Versuche (R 4847 and R 4848, I 8:5). Kant distinguishes his own project from that of Tetens in R 4900 and R 490 I, I 8:23. 
It is plain that Tetens was of considerable importance to Kant. Manfred Kuehn has argued that Tetens provided a crucial link between earlier German empiricist thought such as Feder's, on the one hand, and Kant's, on the other. ${ }^{4}$ As Kuehn states, it is Tetens's philosophy 'that makes clearer than any other Kant's connections with his contemporaries'. Indeed, scholarly interest in Tetens seems to be inspired mainly by his obvious relevance to Kant's thought. There is comparatively little on Tetens's philosophy in its own right, although recently steps have been taken to rectify this. ${ }^{6}$ A somewhat neglected aspect of his relation to Kant is the impact that the early Kant, especially through the Dissertation of I770, had on the development of Tetens's own thought. ${ }^{7}$ Yet most of the literature on Tetens focuses only on the relevance of his Versuche to Kant's Critical philosophy. There is a considerable, if not a huge, amount of work on various aspects of this relation, links between Tetens's and Kant's teachings being discussed on a number of issues. ${ }^{8}$

Indeed, it is not surprising that Kant became interested in Tetens while working on the Critique of Pure Reason in the late I770s. It seems that Tetens's general project was very similar to Kant's, at least in some important respects. Both aimed, in different ways, at overcoming the divide between what later came to be called 'empiricism' and 'rationalism'. Much of early scholarship on Tetens did not sufficiently recognise his concern with this kind of project, however, as it saw him as a

4 Kuehn, Scottish Common Sense in Germany, I768-I800, p. I 2 I. Kuehn provides a detailed account of the influence the Scottish Common Sense philosophy had on Tetens. For other literature on Tetens's philosophy in general, see Sommer, Grundzüge einer Geschichte der deutschen Psychologie, pp. 260-302; Uebele, Johann Nicolaus Tetens nach seiner Gesamtentwicklung betrachtet; Beck, Early German Philosophy, pp. 4I2-25; Barnouw, 'The Philosophical Achievement and Historical Significance of Johann Nicolas Tetens'; Rappard, Psychology as Self-knowledge, pp. 49-83; and Hauser, Selbstbewußtsein und personale Identität, pp. I 24-5 I.

5 Kuehn, Scottish Common Sense, p. I 2 I.

6 Stiening and Thiel (eds.), Johann Nikolaus Tetens (I736-1807).

7 Tetens refers to Kant's Dissertation in several places, for example in Versuche I, pp. 359-60, where he examines the question of how the concepts of space and time are acquired. Corey Dyck has recently dealt with this issue, arguing that Tetens not only identified problems with Kant's early analyses, but also offered his own solution, which in turn anticipated and might even have influenced Kant's thinking in the Critique of Pure Reason and after; cf. Dyck, 'Tetens as a Reader of Kant's Inaugural Dissertation'.

8 For the general relationship between Kant's and Tetens's philosophies, see, for example, Sommer, Grundzüge einer Geschichte der deutschen Psychologie, pp. 280-302; Seidel, Tetens' Einfluß auf die Philosophie Kants; and Carl, Der schweigende Kant, pp. I I 5-26. For more recent accounts of specific aspects of the relationship, see, for example, Heßbrüggen-Walter, 'Kant, Tetens und die Grundkraft der Seele'; Krouglov, 'Der Begriff transzendental bei J. N. Tetens'; Krouglov, 'Tetens und die Deduktion der Kategorien bei Kant'; Wunderlich, Kant und die Bewußtseinstheorien, pp. 69-8I ; Stapleford, 'Reid, Tetens, and Kant on the External World'; and Dyck, Kant and Rational Psychology, pp. 54-6o. 
straightforward empiricist. And Kant, too, when distinguishing himself from Tetens, singles out the empiricist aspects of Tetens's philosophy. Thus he says that 'Tetens examines the concepts of pure reason merely subjectively (human nature), I objectively. The former analysis is empirical, the latter transcendental' (R 490I, I 8:23; see also R 4900). And the label 'the German Locke', first used for Tetens by Karl Rosenkranz in I 840, remains popular, even though the appropriateness of this label has been questioned in recent years. ${ }^{9}$

It is true, however, that Tetens seems to commit himself to an empiricist or observational approach to philosophical problems. In the preface to the Versuche, he presents his work as a 'psychological analysis of the soul'. ${ }^{\text {Io }}$ Explicitly appealing to Locke, he says that his method is observational. The basis for his 'psychological analysis' is the modifications of the soul as they are given through a 'feeling of the self (Selbstgefühl). These are then to be repeated and modified, and attention is to be given to their genesis. The observations are to be compared and analysed so that the most basic faculties and operations and their relations to each other can be discovered. ${ }^{\text {II }}$ It is plain that Tetens was strongly influenced by the Göttingen empiricist philosopher Johann Georg Heinrich Feder, whose very popular textbook, Logik und Metaphysik (Logic and Metaphysics), first published in I 769 , Tetens used for his lectures from the winter term of $1769-1776 .{ }^{\text {I2 }}$ Feder, in turn, was strongly influenced by British philosophy and later criticised Kant's philosophy from an empiricist standpoint.

Tetens's aim is not a mere natural history of the mind, however. He aims at going beyond a collection of observed facts or a mere description of the operations of the soul and their connections, a mere 'mental geography', as Hume put it. Rather, the descriptive account is only Tetens's starting point; his aim is to then discover principles which allow us to infer the causes of mental operations in order 'to establish something certain ... about the nature of the soul, as the subject of the observed operations'. ${ }^{13}$ In short,

9 See, for example, Stiening and Thiel, Johann Nikolaus Tetens, p. I6. Io Versuche I, p. iv.

I 'Was die Methode betrifft, deren ich mich bedient habe, so halte ichs für nöthig, darüber zum voraus mich zu erklären. Sie ist die beobachtende, die Lock bey dem Verstande, und unsere Psychologen in der Erfahrungs-Seelenlehre befolgt haben. Die Modifikationen der Seele so nehmen, wie sie durch das Selbstgefühl erkannt werden; diese sorgfältig wiederholt, und mit Abänderung der Umstände gewahrnehmen, beobachten, ihre Entstehungsart und die Wirkungsgesetze der Kräfte, die sie hervorbringen, bemerken; alsdenn die Beobachtungen vergleichen, aufösen und daraus die einfachsten Vermögen und Wirkungsarten und deren Beziehungen aufeinander aufsuchen' (Versuche I, pp. iii-iv). See also ibid., p. I70.

I2 See Sellhoff, 'Einleitung', in Johann Nikolaus Tetens: Metaphysik, pp. xliv-xlix. As Sellhoff points out, Feder refers to Tetens's Versuche in later editions of Logik und Metaphysik (e.g., I783, \$8, p. 3 I).

I 3 Versuche, I, p. iv. 
Tetens's aim is to establish a metaphysics of the soul, but to do so on an empirical basis. In order to achieve this aim, obviously, reasoning (Raisonnement) is required in addition to observation. 'In the last analysis', Tetens argues, 'the reflections and inferences make the simple observations useful, and without them we would touch merely the surface of things' ${ }^{I 4}$ Tetens would regard a mere mental geography as superficial, as he thinks that philosophy should dig deeper, go beyond the surface of things. Elsewhere, Tetens states explicitly that the observational approach is merely the first step in his investigations and that rational 'speculation' ('Spekulation aus allgemeinen Gründen') is required for philosophy. Like Leibniz in his Nouveaux essais, he even states that one can learn from the 'scholastics' here. ${ }^{\text {Is }}$ This sounds like a far cry from a 'German Locke'. Clearly, there are significant differences between Locke's and Tetens's projects.

To be sure, Locke, too, thinks that reason is just as important as experience in formulating hypotheses about the nature of things that are more probably true than other views. Importantly, however, unlike Tetens, Locke does not think that experience and reason can make out anything certain about the real nature of the soul (or the nature of matter). Its 'real essence', as Locke would have said, remains unknown to us. To describe Tetens's project as straightforwardly empiricist, then, is misleading to say the least. And yet, too often his arguments are said to be problematic because they are inconsistent with his (alleged) 'empiricism'. It may well be that there are inconsistencies in Tetens's account, but this would not be because of any purely 'empiricist' project that he endorsed. Also, his metaphysical conclusions may not be well warranted, or it may be difficult to see how precisely his synthesis of rationalism and empiricism is meant to work, but again, these are different points. Here we need to emphasise his metaphysical aim and his attempt to reconcile empiricist and rationalist strands of thought. Tetens was not a 'German Locke'; rather, like Kant, his project consisted in finding a way beyond the empiricism/ rationalism divide, even if his method and the results are very different, indeed, from Kant's.

Unlike much Tetens scholarship, Kant must have recognised that Tetens pursued a project of that kind. Had he regarded Tetens as a mere empiricist concerned with nothing but the 'evolution of concepts' ( $\mathrm{R} 4900, \mathrm{I} 8: 23$ ), he would hardly have thought of him as one of the very

\footnotetext{
I4 Ibid., p. xxx.

Is Johann Nikolaus Tetens, Ueber die allgemeine speculativische Philosophie, p. 86. See also pp. 73 and 89 .
} 
few thinkers of his day who would be able to 'enlighten the world' about the project of a Critique of Pure Reason. ${ }^{16}$ The fact that Kant was very disappointed when no such enlightening activity on Tetens's part was forthcoming is just a further indication of the high expectations and regard Kant had for Tetens as a philosopher.

My focus in this paper is on an issue that seems to have been somewhat neglected in the literature on Tetens and Kant. It is a central issue for both thinkers, even if Tetens at least does not explicitly describe it as a central topic. This is the notion of the unity of the self. My aim is not to show that Tetens had said what Kant later said, only less precisely, but rather to account for the notion of unity in both thinkers and highlight the similarities and differences and thereby illuminate both thinkers' accounts and their relationship to one another.

\section{Tetens on Inner Sense, Consciousness and Selbstgefühl}

In the comments cited above on his observational method, Tetens makes use of the notion of a 'feeling of the self, or Selbstgefühl. It turns out that this notion is of central importance to his overall project and to the issue of unity in particular. What is this Selbstgefübl, and how is it related to notions such as consciousness and apperception that Tetens also makes use of? The notion of Selbstgefühl is somewhat uncommon in present-day philosophical debates, though it was a popular term in late eighteenth-century writings on empirical psychology and anthropology. It seems that Johann Bernhard Basedow had introduced the term into the philosophical terminology in $1764 .{ }^{17} \mathrm{Obvi}-$ ously, similar expressions, such as 'inneres Gefühl', had been used much earlier, ${ }^{18}$ but 'Selbstgefühl' became popular when Feder took over the term from Basedow in his influential Logik und Metaphysik, mentioned earlier as a textbook that Tetens used for his lectures. ${ }^{19}$ Very probably, then, Tetens adopted this term from Feder. It is not easy, however, to determine the exact meaning of 'Selbstgefühl', as it was used in several different ways by a variety of thinkers. ${ }^{20}$ Here, we focus on Tetens.

${ }^{16}$ Letter to Herz, May I78 I (Corr, I0:270). See also the letter to Garve, 7 August I783 (Corr, I0:34I).

17 Johann Bernhard Basedow, Philalethie, vol. 2, \$r o.

${ }^{\text {I }}$ See, for example, Georg Friedrich Meier, Metaphysik, vol. III, pp. Io and 2 I.

i9 Feder, Logik und Metaphysik (I769), pp. I I 6 and $267 \mathrm{f}$.

${ }^{20}$ For a detailed account of the notion of Selbstgefühl in eighteenth-century thought, see Thiel, 'Varieties of Inner Sense', and for a discussion of Tetens, see Thiel, 'Zwischen Empirischer Psychologie und Rationaler Seelenlehre'. 
Tetens seems to connect Selbstgefühl, considered as a faculty of the soul, with inner sense. Selbstgefühl is 'the feeling of any kind of inner states and modifications considered in themselves, as they exist in us'. ${ }^{21}$ Inner sense is conceived more broadly than Selbstgefühl, however, for the objects of inner sense include 'the relations of objects that are in us, such as the feeling of identity and diversity' as well as the feelings of the beautiful, the morally good and the true. Selbstgefühl, then, considered as a faculty, is a kind of inner sense but not identical with it. Tetens also distinguishes Selbstgefühl from the consciousness of our own mental states, as it denotes the immediately felt presence of mental states, in the sense of what is today called a first-order model, according to which this feeling or awareness is an essential and immanent feature of the mental states themselves. Consciousness, by contrast, understood as a relating to our own mental states, is a secondary act through which those states become conscious in the first place. This is why Tetens argues that consciousness can relate only to past states, not to the immediately present ones: 'One is not conscious to oneself that one is conscious of some object, [one is] not in the former [state], that is, at the same moment at which one is the latter state. We do not reflect on our own reflection at the same moment at which our reflection is occupied with a particular object. ${ }^{122}$ That Tetens uses the terminology of 'reflection' here to account for the consciousness of mental states indicates that he thinks of the latter in terms of a second-order model. In other contexts, however, he appears to account for consciousness in terms of an immediate 'feeling', as we shall see below.

\section{Tetens on Apperception and the Consciousness of Objects}

In accounting for apperception and the consciousness of objects, Tetens seems to follow Christian Wolff rather than the tradition of Locke or Hume, although he uses the terminology somewhat differently from Wolff. $^{23}$ In Tetens, 'apperception' does not stand for self-consciousness, but for 'Gewahrnehmen', or awareness, and is closer to Wolff's 'Bewußtseyn', or consciousness. ${ }^{24}$ Like Wolff in his remarks on consciousness, Tetens

${ }^{21}$ Versuche I, p. I90. ${ }^{22}$ Versuche I, p. 46.

${ }^{23}$ On this latter point, see Wunderlich, Kant und die Bewußtseinstheorien, pp. $75 \mathrm{f}$. , and Thiel, 'Zwischen Empirischer Psychologie und Rationaler Seelenlehre', p. 94. For Wolff, see also Thiel, The Early Modern Subject, pp. 304-I I. For a detailed discussion of Tetens's notion of apperception as Gewahrnehmen, see Kitcher, 'Analyzing Apperception (Gewahrnehmen)'.

24 Thus Watkins translates Tetens's Gewahrnehmen as 'awareness'; cf. Watkins, Background Source Materials, p. 36r. 
accounts for apperception in terms of the notion of distinguishing between things: 'Being aware is a distinguishing. ${ }^{.25} \mathrm{We}$ apperceive an object when we become aware of its distinctness from other objects; the function of apperception is to distinguish objects from each other. ${ }^{26}$ As the act of distinguishing is an activity of the power of thought, Tetens ascribes apperception to thought (Denkkraft). The faculty of thought consists in cognizing 'relations among thingss. ${ }^{27}$ For Tetens, then, apperception is an intellectual faculty. Also, like Wolff (in regard to consciousness), he argues that attention and reflection are necessary conditions of apperception, ${ }^{28}$ and that reflection is to be understood in terms of comparing things or ideas of things. ${ }^{29}$ Tetens points out that what he calls 'Bemerken' involves more than distinguishing among objects; it picks out the characteristics of an object that can serve for re-identifying it in the future. ${ }^{30}$

The consciousness ('Bewußtseyn') of objects, however, is equivalent neither to apperception nor to Bemerken. For Tetens, the consciousness of objects does involve the act of distinguishing (and thus Gewahrnehmen, or apperception). Consciousness of an object, however, is a mental state in which one not only feels (through acts of distinguishing) the object or its representation, but also one's own self as the subject of these activities. Consciousness in this context is a feeling that combines the feeling of the object and the feeling of one's own self. It involves an act of distinguishing between the felt thing and one's own self. ${ }^{3 \mathrm{I}}$ This idea is also present in Wolff. Wolff held that it is through our consciousness of objects that we become conscious of ourselves as something that is distinct from the objects of which we are conscious. Tetens, too, argues that relating to objects and to one's own self belong 'inseparably' together, as he puts it. Without relating to objects, there could be no relating to one's own self. ${ }^{32}$

\footnotetext{
25 Versuche I, p. $262 . \quad{ }^{26}$ Ibid. ${ }^{27}$ Ibid., p. 295. ${ }^{28}$ Ibid., pp. $282-5$.

29 Ibid., p. 264.

30 'Das Bemerken will etwas mehr sagen, als Gewahrnehmen. Wer etwas bemerket, suchet an der wahrgenommenen Sache ein Merkmal auf, woran sie auch in der Folge gewahrgenommen und ausgekannt werden könne' (ibid., p. 263).

3I 'Sich einer Sache bewußt seyn, drucket einen fortdaurenden Zustand aus, in welchem man einen Gegenstand oder dessen Vorstellung unterscheidend fühlet, und sich selbst dazu. Das Bewußtseyn ist von Einer Seite ein Gefühl, ... mit dem ein Unterscheiden der gefühlten Sache und Seiner selbst verbunden ist. Gefühl und Gewahrnhemung sind die beiden Bestandtheile des Bewußtseyns' (ibid.).

32 See ibid., p. 379. Wolff does not merely say that the two concepts are inseparable, however, and that we cannot relate to our own self without also relating to an object, but also that without relating to our own self, we could not relate to objects. Thus he suggests a relation of mutual dependence, though without explaining this idea in any detail (see Wolff, Deutsche Metaphysik,
} 
In the previous section, we noted that Selbstgefühl and being conscious of one's own mental states are two distinct ways of relating to one's own self for Tetens. In the present context, Tetens thinks of consciousness as a complex feeling that involves Selbstgefühl but, again, is not identical with it. Here, consciousness involves a feeling of the apperceived object and the feeling of one's own self. ${ }^{33}$ However, Tetens does not seem to elaborate on the function Selbstgefühl is meant to fulfil for the consciousness of objects. He does not explain why he thinks the feeling of self is involved in our consciousness of objects.

\section{Tetens on the Unity of the Self and Selbstgefuibl}

What, precisely, is the object of Selbstgefühl? Tetens does not seem to be clear on this. Sometimes, following Hume, he claims that only our mental acts or ideas constitute the immediate objects of Selbstgefühl, ${ }^{34}$ and that the notion of a subject or bearer of those mental operations is inferred. This is implied by his definition of Selbstgefühl as a feeling of 'inner modifications' of the soul, i.e., not of the soul itself as the bearer of those modifications. ${ }^{35}$ At other times, he seems to suggest that the self as an embodied soul is an object of feeling. ${ }^{36}$ And against Hume, Tetens argues that Selbstgefühl even leads to the notion of a strictly unitary and identical self and maintains that Hume had simply 'overlooked' this fact. This can be maintained, Tetens believes, by accepting no more as real than Hume does - that is to say, by relating only to those items of which we are immediately conscious. We feel, as Hume would concede, a multiplicity of perceptions; but, Tetens maintains, we feel more than that. ${ }^{37}$ For whenever I feel a

\$730). Compare Thiel, 'Zum Verhältnis von Gegenstandsbewußtsein und Selbstbewußtsein bei Wolff und seinen Kritikern'; Thiel, The Early Modern Subject, pp. 304-I I; and Wunderlich, Kant und die Bewußtseinstheorien, p. 77.

33 Note that Tetens does not equate Selbstgefühl with self-consciousness. In contrast to the former, the latter is a mediated relating to one's own self. Compare Versuche I, pp. 298-9. For a discussion of this, see Thiel, 'Zwischen Empirischer Psychologie und Rationaler Seelenlehre', pp. 95-6, and Wunderlich, Kant und die Bewußtseinstheorien, pp. 77-8.

34 See again the passage from Versuche I, p. I90.

35 'Die innern Modifikationen, deren Gefühl unser Selbstgefühl ausmachet' (ibid., p. I 54). Compare also ibid., II, p. I72.

36 See Versuche II, p. I70: 'What is the object of my feeling when I feel myself and my actions? Pure observation can only answer that I feel the self, the feeling, thinking, and willing whole which consists of a body and a simple soul, the embodied soul.' Compare also: 'Es ist der Mensch, der von dem Menschen gefühlet wird' (ibid., p. I73).

37 'The matter is not as Mr. Hume says it is, and one can assert this without assuming that something more is actually present than what he himself recognises, namely, only as much as we are aware of immediately. But Mr. Hume overlooked one important circumstance. I feel one representation, and 
perception, I am also conscious, he holds, that this feeling is part of a 'larger' and 'stronger' but 'obscure' feeling of a 'ground' (Grund) of my perceptions, which remains the same in all changes of perceptions. This is Tetens's notion of an 'obscure ground', or core, of all our perceptions. Tetens argues:

As often as I have an impression of, am aware of, or become immediately conscious of a representation I am to that extent also conscious that this feeling of my modification is only a prominent aspect of a much larger, more extensive, stronger feeling, though one that is, in its other parts, obscure or at least less clear. And I am just as conscious of this latter [feeling] and in the same way that I can always be with respect to each individual feature of which I become aware, in the same way, namely, that one can ever become immediately conscious of something. Thus I have such an impression that carries me to the thought that a thing and a feature in this thing is present, in the very same way that I can arrive at this thought according to Mr. Hume's own explanation: a feature is actual. And in this whole impression the obscure [back]ground for it is always the same, if I am aware of one aspect of it as presently actual in me instead of another that has faded away. This [back] ground for the whole impression ... is the same throughout all of the particular changes that occur in the impression and the representation. ${ }^{38}$

Tetens's statements about the feeling relating to an 'obscure ground' as a 'larger' and 'stronger' but 'less clear' feeling that is part of any particular perception we feel are left unexplained, however. ${ }^{39}$ In the end, it remains unclear whether Tetens wants to say that we are directly conscious of this 'obscure ground' or that it is suggested to us somehow by the immediate consciousness or feeling of particular perceptions. ${ }^{4}$

Still, for Tetens it follows from this observation that the self is not a mere collection of a multiplicity of ideas that the imagination may then combine into some fictional unity. Rather, there is a natural and real unity of the self. This is why we have the idea of one subject with many modifications. Tetens argues that it is a consequence of his observation about the 'obscure ground',

another, also an activity of thinking, an expression of the will, etc., and these impressions are different and actual. But I have even more impressions' (Versuche I, p. 393; the translation of this passage is from Watkins, Background Source Materials, p. 370).

38 Versuche I, pp. 393-4. The translation of this passage is from Watkins, Background Source Materials, p. 370 .

39 Compare Baumgarten, who calls the totality of our obscure perceptions the 'ground of the soul' (fundus animae; Grund der Seele). Baumgarten, Metaphysica, \$5 I I. For this issue, see also Frank, Selbstgefühl, pp. 203-4.

${ }^{40}$ See also Versuche I, p. 26r: 'Begleitet nicht ein gewisses dunkles Selbstgefühl alle unsere Zustände, Beschaffenheiten und Veränderungen von der leidentlichen Gattung?' 
that the idea or representation of my $I$ is not a collection of individual representations that our imagination might have turned into a whole just like it unifies the individual representations of soldiers into a representation of one regiment. That unification lies in the impression itself, in nature, and not in a combination that it makes itself. For this reason a representation of one subject with different features arises, that is, a representation that immediately arises from the impression, must be thought in this way and turned into an idea such that the common human understanding actually does form it in this way. ${ }^{4 \mathrm{I}}$

\section{Tetens on the Unity of the Self as Appearance and as Substance}

It was a common view in eighteenth-century philosophy that the soul, as a simple substance, is the object of an immediate feeling. In some passages at least, Tetens, too, seems to hold this view. Obviously, however, it is highly problematic to assert that we simply 'feel' that the soul is such an entity. Elsewhere, Tetens argues more cautiously, suggesting that he is aware of the problematic nature of this claim and is attempting to remain metaphysically neutral as to the object of Selbstgefühl. In this context, it is important to highlight a distinction Tetens draws between two ways of thinking about the self. He distinguishes between the soul in a psychological sense ('im psychologischen Verstande') and in a metaphysical sense ('im metaphysischen Verstande'). The latter is not an object of Selbstgefühl, but of 'theoretical speculation', and is thought of as an incorporeal substance. $^{42}$ This, as we shall see, is relevant to the issue of unity. ${ }^{43}$ The human self or soul, considered in a psychological sense, is that self that we feel directly through Selbstgefühl. ${ }^{44}$ Regarding the psychological self, it does not matter, Tetens seems to hold, if the soul consists solely of a simple immaterial essence, of such an immaterial essence in combination with an inner corporeal instrument of feeling and thought, or of only an inner organised body'. ${ }^{45}$ Tetens suggests that we need to distinguish between what is accessible to Selbstgefühl and the ontological ground of the empirical or 'psychological' self. The real essence, as Locke would have put it, of

${ }^{4}$ I Ibid., p. 394. The translation of this passage is from Watkins, Background Source Materials, pp. 370-I.

42 Versuche I, pp. 739-40.

43 For a general account of Kant's and empiricists' conception of unity, see Thiel, 'Unities of the Self: From Kant to Locke'.

44 'Die menschliche Seele im psychologischen Verstande genommen, ist das $I c h$, das wir mit unserm Selbstgefühl empfinden und beobachten können ... Genug es ist das fühlende, denkende und wollende Eins, der innere Mensch selbst' (Versuche I, p. 740).

45 Ibid. 
the self or soul may be of this or that nature, but whatever it is, it is not an object of Selbstgefübl and thus not relevant to the self in an empirical or psychological sense. Strictly speaking, for Tetens, the soul in a psychological sense' is mere appearance ('Schein'): our immediate awareness of the self does not allow us to consider it as anything else but appearance. ${ }^{46}$ As his critique of Hume suggests, however, for Tetens there is unity at the level of inner consciousness and observation. He speaks explicitly of an 'observed unity of the self ${ }^{47}$ Our very Selbstgefühl, Tetens holds, indicates that the self is more than a play of fibres in the brain; it is a unitary entity, not a 'heap of several things'. ${ }^{48}$ Tetens thinks it is a matter of observation that the self that sees is the same as that which tastes, thinks, wills, etc.; there is one unitary entity involved in all mental operations. ${ }^{49}$ Of course, this notion of an empirical unity of the self raises questions: Is this unity really an object of mere observation or feeling, as Tetens maintains? Do we feel this unity, or do we feel only the various inner modifications, as Hume would have objected to Tetens's thesis? In short, is Tetens's alleged 'observed unity' perhaps merely an asserted unity and not a matter of experience at all? Further, even if we assumed with Tetens that there is a feeling of unity, such a feeling could deceive us. We may think, on the basis of inner experience or feeling, that we are unitary beings, without in fact being unitary at all. Tetens would probably have argued that such a feeling, if it exists, cannot be illusory, but indicates the existence of a real unity. If there were no real unity, the feeling of unity would disappear. ${ }^{50}$

Tetens maintains, moreover, that the appearances of Selbstgefühl relate indirectly to the qualities and powers of the soul in a metaphysical sense, to

46 'Was endlich die Natur unsers Selbstgefühls und der Vorstellungen betrifft, die wir von unsern eigenen Wirkungen haben, so können sie ... nichts mehr als Schein seyn; so wie die unmittelbare Beobachtung uns auch nicht berechtiget, sie für etwas mehr anzusehen ... Denn wir empfinden die Aktus unsers Gefühls, und des Denkens, und des Wollens nur in ihren Wirkungen, das ist, in den Veränderungen und Folgen, die davon in dem gesammten Seelenwesen, das ist, in einem zusammengesetzten Wesen abhangen' (Versuche II, p. 212).

47 Ibid., p. I75. $\quad 4^{8}$ Ibid., pp. 178 and I 83.

49 Ibid., p. I9I. Tetens does not deal in any detail with the issue of diachronic personal identity. Although he holds that our very Selbstgefühl leads to the notion of an identical self or 'obscure ground' underlying our perceptions, he is not saying that our identity through time is known to us through a direct feeling. Rather, he argues that the concept of the identity of the self is derived from comparing the present feeling of one's own self, as a subject with certain characteristics, with a similar past feeling that is being reproduced. ('Daher der Begrif von der Identität unsers Ichs, aus der Vergleichung eines gegenwärtigen Gefühls von unserm Ich, als einem Subjekt mit seiner in ihm vorhandenen Beschaffenheit mit einem ähnlichen vergangenen Gefühl, welches reproduciret wird,' Versuche I, p. 394.) Note that Tetens comments here on the way in which we develop the concept of our own identity. He does not seem to explain how the diachronic identity of the self is constituted. Rather, he seems to take diachronic identity for granted.

so Versuche II, p. I97. 
which he refers as the 'simple self. ${ }^{5 I}$ The soul in this sense is a 'simple entity, distinct from the organised body', an immaterial substance. ${ }^{52}$ Tetens accounts for the self in a metaphysical sense in terms of a 'substantial unity of the soul'. ${ }^{53}$ But how, according to Tetens, do we arrive at the notion of a metaphysical and substantial unity? His critique of Hume's bundle account of the mind suggests that the simple, incorporeal self is itself an object of inner experience and is part of that totality that we feel when we are conscious of 'inner modifications'. Elsewhere, however, Tetens argues that immediate experience merely 'suggests' the notion of an incorporeal self or, more strongly, that we are 'forced' to come up with this notion from immediate experience. ${ }^{54}$ Clearly, if experience merely suggests the idea of unity, then this idea is not an object of direct experience or Selbstgefühl. Moreover, Tetens seems to be saying in another passage that 'theoretical speculation about the nature of the soul' is required in order to arrive at the idea of a substantial unity. ${ }^{55}$

Indeed, Tetens seems to argue for the idea of a unitary soul by way of reflecting on the conditions of experience and thought in general. This argument appears in the context of his attempt to answer his own question about how we arrive at the notion of a substantial unity. Again, if the substantial unity has to be inferred, then it is not immediately given in experience or Selbstgefühl. Clearly, as we shall see, Tetens employs a method that goes well beyond the empiricist strands of his thought.

Tetens's first step in answering his question about substantial unity is to show that in order to have representations of external objects, an activity of judging or forming propositions is required, and that in order to be able to do the latter, an activity of distinguishing between the external thing, the representation, and one's own self is required. ${ }^{56}$ Tetens does not mention the notion of substantial unity here, but he introduces a notion of a self that is not an object of feeling or experience. Rather, it is the notion of something that we have to think in order to be able to explain representations of external objects. Without such a notion of the self, as distinct from

รI 'Erscheinungen ..., die sich ... mittelbar auf die Beschaffenheiten, Kräfte und Vermögen des einfachen Ichs beziehen' (ibid., pp. 21 2-I3).

52 Versuche I, p. 739. $\quad 53$ Versuche II, p. I75. $\quad 54$ Ibid., p. I78. $\quad 55$ Versuche I, p. 740.

56 'Mit allen Vorstellungen des Gesichts, des Gefühls und der übrigen Sinne wird der Gedanke verbunden, dass sie äußere Objekte vorstellen. Dieser Gedanke bestehet in einem Urtheil, und setzet voraus, dass schon eine allgemeine Vorstellung von einem Dinge, von einem wirklichen Dinge, und von einem äußern Dinge, vorhanden, und dass diese von einer andern allgemeinen Vorstellung von unserm Selbst, und von einer Sache in uns, unterschieden sey' (ibid., p. 344). 
the representation of other things, the possibility of forming propositions about the existence of external things could not even be entertained. This notion is a requirement of thought.

Next, Tetens attempts to show that the required notion of the self is that of a unitary substance or a 'substantial unity'. Without such a unity, the operations of the soul would not be possible. He argues that 'the collective powers and operations presuppose a substantial unity in which the collection is performed and with respect to which they are only such powers and operations as they are'. ${ }^{57}$ Even individual operations presuppose such a unity, Tetens argues. Such operations consist of a multitude of elements. These elements can become one single act only if they belong to a substantial unity. ${ }^{58} \mathrm{He}$ argues, further, that the very act of forming a judgement or proposition presupposes the unity of the self. In order to form even the most basic proposition, we need to combine subject, predicate and the relation between the two. This combination would not be possible if there were no unitary self to which these various thoughts belonged. ${ }^{59}$

In sum, there are three notions of the unity of the self in Tetens. First, there is the empirical, observed or observable unity relating to the self in a psychological sense, a unity that is simply a fact of consciousness or inner experience. ${ }^{60}$ Second, as Tetens obviously thinks that the observed unity of the psychological self is not sufficient, there is the idea of substantial unity that relates to the self in the metaphysical sense, understood as an immaterial entity. Rational reflection, rather than merely feeling and observation, is required to arrive at the notion of a substantial unity. As we saw, one reflection that is relevant here is that the nature of having representations or mental activity leads, third, to the idea of unitary self as a necessary condition of such activity. Importantly, for Tetens, the notion of the unity of the self as a necessary condition of mental activity collapses into the second, the substantial unity. For Tetens, the unity of the self as a necessary condition of mental activity can be none other than the unity of the soul as a substance, the self in a metaphysical sense.

\footnotetext{
57 Versuche II, p. I75.

58 'Denn wenn die verschiedenen Bestandtheile des Aktus durch mehrere verschiedene Wesen vertheilet sind, davon jedes einzeln, nur einen einzelnen von jenen Aktus hervorbringet: so ist zwar ein Haufen von Elementen des Gefühls in mehrern Dingen vertheilt vorhanden; aber nirgends ist ein Gefühl, nirgends das vereinigte Ganze aus ihnen, das nach der Voraussetzung, heterogen von seinen Elementen, erst ein Gefühl wird, wenn jene Elemente zusammen genommen werden' (ibid., p. I97).

59 Ibid., p. I95.

6o 'So zeiget sich unmittelbar aus den Beobachtungen eine gewisse Einheit unsers Ichs' (ibid., p. I9I).
} 


\section{Tetens's Conceptions of Unity and Kant}

Like Tetens, Kant distinguishes between three conceptions of the unity of the self, if in a very different systematic context. Kant distinguishes between what he calls the psychological or empirical, the logical or transcendental and the noumenal self. ${ }^{6 \mathrm{I}}$ There seem to be some significant similarities between Tetens's and Kant's distinctions. Thus Tetens's distinction between the self in a psychological sense and the self in a metaphysical sense may be seen as corresponding to Kant's distinction between the psychological self and the noumenal self, and Tetens's notion of unity as a necessary condition of mental activity as corresponding to the transcendental unity of apperception in Kant. On the other hand, the three conceptions and their relationships to one another are not equivalent in Kant and Tetens. Let us look, first, at Kant's notion of the empirical or psychological self in comparison with Tetens's notion of the soul in a psychological sense.

Kant argues that unity is required for thought and cognition to be possible. This leads to his notion of the transcendental unity of apperception in the Transcendental Deduction of the Categories. In order to introduce and clarify this notion, he contrasts it with empirical apperception, or inner sense. Empirical consciousness of oneself, or apperception, is the actual awareness of particular mental states. Kant says that empirical apperception 'accompanies different representations'. This means that it 'is by itself dispersed' (BI33): 'The consciousness of oneself in accordance with the determinations of our state in internal perception is merely empirical, forever variable; it can provide no standing or abiding self in this stream of inner appearances, and is customarily called inner sense, or empirical apperception (AI07), ${ }^{62}$ Inner sense, or empirical apperception, does not provide us with the notion of a unitary self or subject, because 'all the determining grounds of my existence that can be encountered in me are representations' (Bxxxix). I do not encounter a unitary self beyond the representations. Rather, 'in that which we call the soul, everything is in continual flux', and inner sense 'gives cognition only of a change of determinations' (A38I). Empirical apperception, then, is just a consciousness accompanying different perceptions and is, for that reason, 'forever variable' (Ar 07).

6I Kant distinguishes between the self of empirical apperception or inner sense and the self of pure apperception in terms of the notion of the "psychological self and the 'logical self in RP, 20:270.

62 See also Anth, 7:I 34 . 
In contrast to Tetens, then, for Kant there is no 'observed unity' of the psychological self based on inner sense alone. The psychological self, rather, is 'by itself dispersed'. In terms of the psychological self, Kant appears to side with Hume rather than Tetens. Like Hume, he holds that direct inner experience provides no evidence for a unitary self; we encounter only perceptions or representations. For Kant, Hume is right in arguing that we cannot find an impression of a self among the perceptions of inner sense. Inner sense, on its own, acquaints us only with constantly changing perceptions, but not with a unitary and identical self.

Second, how does Tetens's idea of a unitary self as a necessary condition of mental activity compare with Kant's doctrine of the transcendental unity of apperception? This question is directly linked to the third question: How does Tetens's account of substantial unity of the self in a metaphysical sense compare with Kant's reflections on the unity of the self in the noumenal sense?

Although Kant agrees with Hume in terms of the psychological self, he thinks that Hume is mistaken in his view that all we can learn about the unity of the self has to be derived from experience. Thinking consists in combining representations, and this combination would not be possible without a prior unity. "The concept of combination ... carries with it the concept of the unity of the manifold' (B $\mathrm{B}_{30}$ ). Representations $a$ and $b$ could not be combined if they did not belong to one and the same consciousness or the same $I$. "The representation of this unity ... first makes the concept of combination possible' (B $\mathrm{B}_{3} \mathrm{I}$ ). Kant speaks, therefore, of a 'necessary unity of apperception' ( $\left.\mathrm{B}_{1} 35\right)$ as a condition of 'thinking in general' (B423). Moreover, as combination is not 'given through objects', 'but can be executed only by the subject itself and is an 'act of its selfactivity' ( $\left.\mathrm{B}_{1} 30\right)$, it 'cannot be regarded as belonging to sensibility' ( $\mathrm{B}_{132}$ ). That is why this unity needs to be distinguished from empirical apperception, is called 'pure apperception' and belongs to the understanding. The $I$ in the proposition $I$ think is a 'purely intellectual' representation precisely because it necessarily 'occurs in all thinking' (B400). For that reason, it is logically prior to the latter; it 'precedes a priori all $m y$ determinate thinking' (BI34). That is what Kant means when he says that the $I$ of pure apperception is only of 'logical significance' (A350).

Kant emphasises that the distinction between the 'psychological self and the 'logical self of pure apperception (RP, 20:270) must not be understood in terms of an ontological distinction between two distinct beings. He states: that 'I am conscious of myself is a thought that contains a twofold self, the self as subject, and the self as object' (RP, 20:270), 
but he insists that this does not mean that there are 'two subjects in one person' (RP, 20:268); rather, the self as thinking subject and the self as a sensory being are 'one and the same subject' (Anth, 7:I42). The distinction between the two is one concerning two ways of relating to the self or of becoming conscious of oneself, the self as a subject of thought and the self as an object of possible experience. ${ }^{63}$

Kant characterises the $I$ of pure apperception or the logical subject of thinking as 'simple' (BI35, B404, B4I9, B420). This means that in all thought it is a single thing that cannot be resolved into a plurality of subjects' (B407). The $I$ of apperception must be one, because otherwise a multiplicity of representations could not be combined into the unity of a thought. Moreover, simplicity here means that the $I$ of pure apperception is empty of content (B404). And this, in turn, means that through the I of pure apperception (in contrast to the psychological self), 'nothing manifold is given' (B I 35). Kant explains the simplicity of the logical subject in terms of logical unity. 'I am simple signifies no more than that this representation $I$ encompasses not the least manifoldness within itself, and that it is an absolute (though merely logical) unity' (A355; compare $\left.A_{35} 6\right)^{64}$

We saw that for Tetens, too, the unity of the self is a necessary condition of mental activity, that is, of cognition. Tetens's account of the unity of the self as a necessary condition of mental activity is not, however, transcendental in Kant's sense of the term, but 'transcendent'. ${ }^{65}$ We saw that for Tetens, the notion of unity as a necessary condition of thought and cognition collapses into that of a substantial unity of the self in a metaphysical sense. For him, the unity of the self as a necessary condition of thought is to be accounted for in terms of the unity of the soul as a substance. Kant would reject this, of course. Indeed, some of Kant's arguments against rational psychology would apply to Tetens's position. Like rational psychology, Tetens's account of the soul in the metaphysical sense makes knowledge claims about the self beyond possible experience,

63 'Es wird dadurch aber nicht eine doppelte Persönlichkeit gemeynt, sondern nur Ich, der ich denke und anschaue, ist die Person, das Ich aber des Objectes, was von mir angeschauet wird, ist gleich anderen Gegenständen außer mir, die Sache' (RP, 20:270). Compare the distinction in the Anthropology between 'the self as the subject of thought' (Anth, 7:I34), also referred to as 'the self of reflection' (Anth, 7:I4I), and 'the self as the object ... of inner sense' (Anth, 7:I 34), also referred to as 'the self of apprehension' (Anth, 7:I42).

64 Beck suggests that Tetens's Selbstgefühl can be linked to Kant's unity of apperception, but this seems implausible, as the former, unlike the latter, is empirical and relates to the soul in a psychological sense; see Beck, Early German Philosophy, p. 419.

65 For Tetens's use of the term 'transcendental', see Krouglov, 'Der Begriff “transzendental” bei J. N. Tetens'. 
thus moving 'beyond the sensible world, entering into the field of noumena' (B409-IO). Kant would argue that, like the rational psychologists, Tetens illicitly infers the substantiality and simplicity of the soul from what Kant calls the $I$ of apperception, or the 'constant logical subject of thinking' (A350). Tetens's error is that he takes the logical unity of consciousness 'for an intuition of the subject as an object' and applies 'the category of substance ... to it' (B42I). In terms of the rationalist claim about simplicity that Tetens seems to adopt, Kant argues that here an analytic truth about logical simplicity is misread as a synthetic truth about the simple nature of the self as substance $\left(\mathrm{B}_{408}\right)$. As Kant points out, 'the simplicity of consciousness is ... no acquaintance with the simple nature of our subject' (A360).

In contrast to Tetens, then, Kant keeps the idea of unity as a formal condition of thought and cognition distinct from the notion of substantial unity. The latter cannot be derived from the former. We are acquainted with the unity of consciousness 'only because we have an indispensable need of it for the possibility of experience' (B420). Still, in spite of such significant differences, as Kant was studying the psychology of the day in the late I770s, it may well be that Tetens's account of the unity of the self played a role in the development of his own ideas on this issue. ${ }^{66}$ However, while Tetens aimed at developing a metaphysics of the soul on an empirical basis, attempting to combine 'empiricism' and 'rationalism' in this way, Kant argued against both empiricist and rationalist accounts in showing that neither experience nor pure reason could function as the basis of a rationalist metaphysics of the soul.

${ }^{66}$ On this topic, see Winter, 'Seele als Problem in der Transzendentalphilosophie Kants', especially p. I24. 


\section{Bibliography}

\section{Primary Sources}

[anon]. [review of] Johann Georg Heinrich Feder, Untersuchungen über den menschlichen Willen, Erster Theil. Zweite, verbesserte Auflage (Göttingen and Lemgo: Meyer, 1785), Allgemeine Literatur-Zeitung, I6 January I787, pp. I 2 I -6 .

Arnauld, Antoine and Pierre Nicole, Logic or the Art of Thinking [1662], Jill Vance Buroker ed. and transl. (Cambridge: Cambridge University Press, I996).

Basedow, Johann Bernhard, Philalethie. Neue Aussichten in die Wabrheiten und Religion der Vernunft bis in die Gränzen der glaubwürdigen Offenbarung, 2 vols. (Altona: Iversen, I764).

Baumgarten, Alexander Gottlieb, Ethica philosophica [1740], 3rd edn. (Halle: Hemmerde, I763; repr. Hildesheim: Olms, 1969).

Initia philosophiae practicae primae (Halle: Hemmerde, 1760).

Metaphysica / Metaphysik. Historisch-kritische Ausgabe, Günter Gawlick and Lothar Kreimendahl, eds. and transl. (Stuttgart-Bad Cannstatt: FrommannHolzboog, 20I I).

Metaphysics. A Critical Translation with Kant's Elucidations, Selected Notes, and Related Materials, Courtney D. Fugate and John Hymers eds. and transl. (London: Bloomsbury, 2013).

Bernoulli, Daniel, Theses Logicae, sistentes Methodum examinandi Syllogismorum validitatem (Basel: Brandmüller, 1722); repr. in Die Werke von Daniel Bernoulli, vol. I: Medizin und Physiologie, Mathematische Jugendschriften, Postitionsastronomie, David Speiser ed. (Basel: Birkhäuser, I996), pp. 257-64.

Bernoulli, Johann and Gottfried Wilhelm Leibniz, Got. Gul. Leibnitii et Johan. Bernoullii Commercium philosophicum et mathematicum, 2 vols. (Lausanne and Geneva: Bousquet, I745).

Blumenbach, Johann Friedrich, The Anthropological Treatises of Johann Friedrich Blumenbach, Thomas Bendyshe transl. (London: Longman, Green, Longman, Roberts, and Green, I865).

Beyträge zur Naturgeschichte. Erster Theil (Göttingen: Dieterich, I790; 2nd edn. I806); Beyträge zur Naturgeschichte. Zweyter Theil (Göttingen: Dieterich, I8II). 
De generis humani varietate nativa (Göttingen: Rosenbusch, I776; 2nd edn. Göttingen: Vandenhoeck, I78I; 3rd edn. Göttingen: Vandenhoeck \& Ruprecht, I795).

Handbuch der Naturgeschichte (8th edn., Göttingen: Dieterich, I 807).

The Institutions of Physiology [18 10 ], $3 \mathrm{rd}$ and final edn., John Elliotson transl. (Philadelphia: Warner, I8I7).

"Prof. Blumenbach über den Bildungstrieb (Nisus formativus) und seinen Einfluß auf die Generation und Reproduction," Göttingisches Magazin der Wissenschaften und Litteratur, 5 Stück (I780), pp. 247-66.

[review of] "Sam. Th. Sömmerring über die körperliche Verschiedenheit des Mohren vom Europäer. I784," Göttingische Anzeigen von gelehrten Sachen, vol. I (22 January I785), pp. Io8-I I.

Über den Bildungstrieb und das Zeugungsgeschäfte (Göttingen, I78I; 2nd edn. I789; 3 rd edn. I79I under the title Über den Bildungstrieb).

Bök, August Friedrich (ed.), Sammlung der Schriften, welche den logischen Calcul Herrn Prof. Ploucquets betreffen (Frankfurt and Leipzig, I766).

Camper, Peter, Über den natürlichen Unterschied der Gesichtszüge in Menschen verschiedener Gegenden und verschiedenen Alters; über das Schöne antiker Bildsäulen und geschnittener Steine; nebst Darstellung einer neuen Art, allerlei Menschenköpfe mit Sicherheit zu zeichnen, Adrian Gilles Camper ed., Samuel Thomas Soemmerring transl. (Berlin: Voss, I792).

Canz, Israel Gottlieb, Überzeugender Beweiß aus der Vernunft. Antreffend die Unsterblichkeit sowohl der Menschlichen Seelen insgemein, als besonders der Kinder-Seelen. Samt einem Anhang, wie es der Seele nach dem Tod zu Muth seyn werde? (Tübingen: Cotta, I74I).

Uberzeugender Beweiß aus der Vernunft von der Unsterblichkeit sowohl der Menschen Seelen insgemein, als besonders der Kinder-Seelen (Tübingen: Cotta, I744).

Cicero, Marcus Tullius, Abhandlung über die menschlichen Pflichten in drey Büchern aus dem Lateinischen des Marcus Tullius Cicero, Christian Garve transl. (Breslau: Korn, I783).

On Duties, M. T. Griffin ed. and transl. (Cambridge: Cambridge University Press, I991).

Crusius, Christian August, Anleitung über natürliche Begebenheiten ordentlich und vorsichtig nachzudencken, 2 vols. (Leipzig: Gleditsch, 1749).

Anweisung, vernünftig zu leben, darinnen nach Erklärung der Natur des menschlichen Willens die natürlichen Pflichten und allgemeinen Klugheitslehren im richtigen Zusammenhange vorgetragen werden (Leipzig: Gleditsch, I744); repr. in Crusius, Die philosophischen Hauptwerke, vol. I.

Die philosophischen Hauptwerke, Giorgio Tonelli ed., vol. IV, Sonia Carboncini and Reinhard Finster eds., 4 vols. in 5 (Hildesheim: Olms, I964-88).

Entwurf der nothwendigen Vernunft-Wahrheiten, wiefern sie den zufälligen entgegen gesetzet werden (Leipzig: Gleditsch, I745); repr. in Crusius, Die philosophischen Hauptwerke, vol. II; 2nd edn., I753. 
Weg zur Gewissheit und Zuverläßigkeit der menschlichen Erkenntnis (Leipzig: Gleditsch, I747); repr. in Crusius, Die philosophischen Hauptwerke, vol. III.

Descartes, René, Oeuvres de Descartes, Charles Adam and Paul Tannery eds., revised edn., I 2 vols. (Paris: Vrin, I964-76).

The Philosophical Writings of Descartes, John Cottingham, Robert Stoothoff and Dugald Murdoch eds. and transl., 3 vols. (Cambridge: Cambridge University Press, I985-9I).

Eberhard, Johann August, Sittenlehre der Vernunft (Berlin: Nicolai, I78 I; repr. Hildesheim: Olms, 20 I I).

Engel, Johann Jakob, Der Philosoph für die Welt, 2 vols. (Leipzig: Dyck, I777).

Euler, Leonhard, Letters of Euler to a German Princess, vol. I, Henry Hunter transl. (London: Hunter and Murray, I795).

Lettres à une princesse d'Allemagne, vol. I (St. Petersburg: Academie impériale des sciences, I768).

"Reflexions sur l'espace et le tems," Mémoires de l'académie des sciences de Berlin 4 (1748/50), pp. 324-33.

Feder, Johann Georg Heinrich, Abhandlung über die allgemeinsten Grundsätze der praktischen Philosophie zum dritten Theil der Untersuchungen über den menschlichen Willen (Lemgo: Meyer, I793).

[review of] Carl Christian Erhard Schmid, Versuch einer Moralphilosophie (1790), Philosophische Bibliothek 4 (I79I), pp. I38-55.

Grundlehren zur Kenntniß des menschlichen Willens und der natürlichen Gesetze des Rechtsverhaltens (Göttingen: Dieterich, I782; 3rd edn., I789).

Grundriß der Philosophischen Wissenschaften nebst der nöthigen Geschichte, zum Gebrauch seiner Zuhörer (Coburg: Findeisen, I767).

[review of] Immanuel Kant, Grundlegung zur Metaphysik der Sitten, Göttingische Anzeigen von gelehrten Sachen, 29 October I785, pp. I739-44 (repr. in Rezensionen zur Kantischen Philosophie $1781-87$, Albert Landau ed. [Bebra: Landau, I99I, pp. 230-3]).

[review of] Immanuel Kant, Kritik der praktischen Vernunft, Philosophische Bibliothek I ( I788), pp. I82-2 I8.

[review of] Immanuel Kant, Träume eines Geistersehers, Erlangische gelehrte Anmerkungen und Nachrichten, 2 I (I766), pp. 308-9 (repr. in Immanuel Kant, Träume eines Geistersehers, erläutert durch Träume der Metaphysik, Rudolf Malter ed. [Stuttgart: Reclam, 1976], pp. I 25-7).

J. G. H. Feder's Leben, Natur und Grundsätze. Zur Belehrung und Ermunterung seiner lieben Nachkommen, Karl August Ludwig Feder ed. (Leipzig: Schwickert I 825; repr. Brussels: Culture et Civilisation, I970).

Lehrbuch der praktischen Philosophie, 2 vols. (Göttingen and Gotha: Dieterich, I770; 3 rd edn., Hanau and Leipzig, I775).

Logik und Metaphysik (Göttingen and Gotha: Dieterich, I769; 3rd edn. Vienna: Trattner, I783).

"Über die Kantische Moraltheologie," Philosophische Bibliothek 3 (I790), pp. I3-66. 
"Ueber das moralische Gefühl," Deutsches Museum I (I776), pp. I 5-40, I03-I 5, 287-306, 479-503; 2 (I777), pp. 7I2-30 (repr. Copenhagen and Leipzig: Faber und Nitschke, I792).

Ueber Raum und Caussalität zur Prüfung der Kantischen Philosophie (Göttingen: Dieterich, I787; repr. Brussels: Culture et Civilisation, I968).

Untersuchungen über den menschlichen Willen, dessen Naturtriebe, Veränderlichkeit, Verhältniß zur Tugend und Glückseligkeit und die Grundregeln, die menschlichen Gemüther zu erkennen und zu regieren. Erster Theil (Göttingen and Lemgo: Meyer, I779); Untersuchungen über den menschlichen Willen. Zweyter Theil (Göttingen and Lemgo: Meyer, I782); Untersuchungen über den menschlichen Willen. Dritter Theil (Göttingen and Lemgo: Meyer, I786); Untersuchungen über den menschlichen Willen. Vierter Theil (Göttingen and Lemgo: Meyer, I793); repr. vols. I-IV (Brussels: Culture et Civilisation, I968).

Untersuchungen über den menschlichen Willen, dessen Naturtriebe, Verschiedenheiten, Verhältniß zur Tugend und Glückseligkeit und die Grundregeln, die menschlichen Gemüther zu erkennen und zu regieren. Erster Theil. Zweyte verbesserte Auflage (Göttingen and Lemgo: Meyer, I785); Untersuchungen über den menschlichen Willen. Zweyter Theil. Zweyte verbesserte Auflage (Göttingen and Lemgo: Meyer, 1787).

Forster, Georg, A Voyage around the World [1777], 2 vols., Nicholas Thomas and Oliver Berghof eds. (Honolulu: University of Hawaii Press, 2000).

"Noch etwas über die Menschenraßen," Teutscher Merkur (October/November I786), pp. 57-86, I 50-66; Engl. transl. "Something More about the Human Races," in Kant and the Concept of Race. Late EighteenthCentury Writings, Jon M. Mikkelsen ed. (Albany: SUNY Press, 2013), pp. I 43-67.

Frederick II, King of Prussia, Ueber die deutsche Litteratur, die Mängel, die man ihr vorwerfen kann, die Ursachen derselben und die Mittel sie zu verbessern, Christian Konrad Wilhelm von Dohm transl. (Berlin: Decker, I780).

Garve, Christian, "Anmerkungen des Uebersetzers," in Adam Ferguson, Grundsätze der Moralphilosophie. Uebersetzt und mit einigen Anmerkungen versehen von Christian Garve (Leipzig: Dyck, I772) (repr. in Reception of the Scottish Enlightenment in Germany: Six Significant Translations, I755-I782, Heiner F. Klemme ed. [Bristol: Thoemmes, 2000]).

Philosophische Anmerkungen und Abhandlungen zu Cicero's Büchern von den Pflichten [1783]. Neue verbesserte und mit einigen Anmerkungen vermehrte Ausgabe (2nd edn.), 3 vols. (Breslau: Korn, I787).

Garve, Christian and Johann Georg Heinrich Feder, "Critik der reinen Vernunft. Von Immanuel Kant. I78I," Zugabe zu den Göttingischen Anzeigen von gelehrten Sachen (January I9, I782), pp. 40-8 (transl. in Kant's Early Critics: The Empiricist Critique of the Theoretical Philosophy, Brigitte Sassen ed. [Cambridge: Cambridge University Press, 2000], pp. 53-4).

Girtanner, Christoph, Ueber das Kantische Prinzip für die Naturgeschichte (Göttingen: Vandenhoek und Ruprecht, I796). 
Hamann, Johann Georg, Briefwechsel I730-I788, Arthur Henkel ed. (Wiesbaden: Insel-Verlag, 1959) (vol. 4 of Briefwechsel, Walther Ziesemer and Arthur Henkel eds., I955-9).

Hegel, Georg Wilhelm Friedrich, Lectures on the History of Philosophy: The Lectures of I 825-26: Medieval and Modern Philosophy, Robert F. Brown ed., Robert F. Brown and J. M. Stewart transl. (Berkeley: University of California Press, I990) (vol. III of Lectures on the History of Philosophy).

Hennings, Justus Christian, Geschichte von den Seelen der Menschen und Thiere (Halle: Gebauer, I774).

Herder, Johann Gottfried, Outlines of a Philosophy of the History of Man, T. Churchill transl. (London: Johnson, I8oo; repr. New York: Bergman Publishers, 1966).

Holst, Johann Ludolf, Über das Fundament der gesammten Philosophie des Herrn Kant (Halle: Hendel, I79I).

Hume, David, A Treatise of Human Nature, David Fate Norton and Mary J. Norton eds. (Oxford: Clarendon Press, 20 I I).

Jacobi, Friedrich Heinrich, The Main Philosophical Writings and the Novel Allwill, George Di Giovanni ed. and transl. (Montreal: McGill-Queen's University Press, 2009).

Kant, Immanuel, Anthropology, History, and Education, Günter Zöller and Robert Louden ed. and transl., The Cambridge Edition of the Works of Immanuel Kant (Cambridge: Cambridge University Press, 2007).

Correspondence, Arnulf Zweig ed. and transl., The Cambridge Edition of the Works of Immanuel Kant (Cambridge: Cambridge University Press, 1999).

Critique of Pure Reason, Paul Guyer and Allen W. Wood eds. and transl., The Cambridge Edition of the Works of Immanuel Kant (Cambridge: Cambridge University Press, I999).

Critique of the Power of Judgment, Paul Guyer transl., The Cambridge Edition of the Works of Immanuel Kant (Cambridge: Cambridge University Press, 2000).

Kant's Gesammelte Schriften, published by Königlich-Preussische Akademie der Wissenschaften (Berlin, I900-19; De Gruyter, I920-).

Lectures on Anthropology, Robert Louden and Allen Wood eds. and transl., The Cambridge Edition of the Works of Immanuel Kant (Cambridge: Cambridge University Press, 2013).

Lectures on Ethics, Peter Heath and Jerome Schneewind eds. and transl., The Cambridge Edition of the Works of Immanuel Kant (Cambridge: Cambridge University Press, 1997).

Lectures on Logic, J. Michael Young ed. and transl., The Cambridge Edition of the Works of Immanuel Kant (Cambridge: Cambridge University Press, I992).

Lectures on Metaphysics, Karl Ameriks and Steve Naragon eds. and transl., The Cambridge Edition of the Works of Immanuel Kant (Cambridge: Cambridge University Press, 200I).

Logik-Vorlesung: Unveröffentlichte Nachschriften, 2 vols., Tillmann Pinder ed. (Hamburg: Meiner, 1998). 
Natural Science, Eric Watkins ed. and transl., The Cambridge Edition of the Works of Immanuel Kant (Cambridge: Cambridge University Press, 2012).

Notes and Fragments, Paul Guyer ed. and trans., The Cambridge Edition of the Works of Immanuel Kant (Cambridge: Cambridge University Press, 2005).

Practical Philosophy, Mary J. Gregor ed. and transl., The Cambridge Edition of the Works of Immanuel Kant (Cambridge: Cambridge University Press, I996).

Religion and Rational Theology, George di Giovanni and Allen Wood eds. and transl., The Cambridge Edition of the Works of Immanuel Kant (Cambridge: Cambridge University Press, I 996).

Theoretical Philosophy 1755-70, David Walford ed. and transl., in collaboration with Ralf Meerbote, The Cambridge Edition of the Works of Immanuel Kant (Cambridge: Cambridge University Press, 2003).

Theoretical Philosophy after I78I, Gary Hatfield, Michael Friedman, Henry Allison and Peter Heath eds. and transl., The Cambridge Edition of the Works of Immanuel Kant (Cambridge: Cambridge University Press, 2010).

Knutzen, Martin, Commentatio philosophica de humanae mentis individua natura, sive immaterialitate (Königsberg: Hartung, I74I).

Elementa philosophiae rationalis seu logicae (Königsberg and Leipzig: Hartung, I747).

Lambert, Johann Heinrich, Abhandlung vom Criterium Veritatis. Mit einem erläuternden Vorwort aus dem Manuskript herausgegeben von Dr. K. Bopp (I76I) (Berlin: Reuther und Reichard, I9I 5) (=Kant-Studien Ergänzungshefte 36).

Anlage zur Architectonic, oder Theorie des Einfachen und des Ersten in der philosophischen und mathematischen Erkenntniß (Riga: Hartknoch, I77I) (Philosophische Schriften, vol. III, Hans Werner Arndt ed. [Hildesheim: Olms, I965]).

Cosmologische Briefe über die Einrichtung des Weltbaues (Augsburg: Klett, 1761).

"De universaliori calculi idea disquisitio" Nova Acta Eruditorum, I764-5, pp. 44I-73.

Neues Organon, oder Gedanken über die Erforschung und Bezeichnung des Wahren und dessen Unterscheidung vom Irrtum und Schein, 2 vols. (Leipzig: Wendler, 1764) (repr. in Philosophische Schriften, vols. I-II, Hans Werner Arndt ed. [Hildesheim: Olms, I965]).

Texte zur Systematologie und zur Theorie der wissenschaftlichen Erkenntnis, Geo Siegwart ed. (Hamburg: Meiner, I988).

Über die Methode, die Metaphysik, Theologie und Moral richtiger zu beweisen. Aus dem Manuskript herausgegeben von K. Bopp (Berlin: Reuther und Reichard, I9I8) (=Kant-Studien Ergänzungshefte 42).

Lange, Samuel Gotthold, Versuch, des von dem Herrn Georg Friedrich Meyer, öffentlichen ordentlichen Lehrer der Weltweisheit zu Halle, in seinen Gedancken von dem Zustande der Seele nach dem Tode geleugneten mathematischen Erweises der Unsterblichkeit der Seele ... (Bernburg: Coerner, I749).

Leben Georg Friedrich Meiers, (Halle: Gebauer, I778). 
Leibniz, Gottfried Wilhelm, "De formae logicae comprobatione per linearum ductus" [I686], in Opuscules et Fragments inédits de Leibniz, extraits des manuscrits de la Bibliothèque royale de Hanovre, Louis Couturat ed. (Paris: Alcan, I903), pp. 292-8.

"Dissertatio de arte combinatoria" [1666], in Die philosophischen Schriften von Gottfried Wilhelm Leibniz, vol. IV, Carl Immanuel Gerhardt ed. (Berlin: Weidmann, I875-90), pp. 27-I04.

"Fundamenta calculi ratiocinatoris" [1688], in Gottfried Wilhelm Leibniz: Sämtliche Schriften und Briefe, vol. VI.4, Berlin-Brandenburgische Akademie der Wissenschaften and Akademie der Wissenschaften zu Göttingen ed. (Berlin: Akademie-Verlag, I999), pp. 917-22.

"Generales inquisitiones de analysi notionum et veritatum" [I686] in Opuscules et Fragments inédits de Leibniz, extraits des manuscrits de la Bibliothèque royale de Hanovre, Louis Couturat ed. (Paris: Alcan, I903), pp. 356-99.

Mathematische Schriften von Gottfried Wilhelm Leibniz, vol. IV, Carl Immanuel Gerhardt ed. (Halle: Schmidt, I 859 ).

"The Principles of Philosophy, or the Monadology (I7I4)," in Philosophical Essays, Roger Ariew and Daniel Garber eds. (Indianapolis: Hackett, I989), pp. 2I3-25.

"Specimen calculi universalis" [1679], in Die philosophischen Schriften von Gottfried Wilhelm Leibniz, vol. VII, Carl Immanuel Gerhardt ed. (Berlin: Weidmann, I875-I890), pp. 218-27.

Locke, John, An Essay concerning Human Understanding, Peter H. Nidditch ed. (Oxford: Clarendon Press, I975).

Löscher, Valentin Ernst, Auserlesene Sammlung der besten und neuern Schrifften vom Zustand der Seele nach dem Tod (Dresden: Sauereßig, I735).

Maimon, Salomon, Salomon Maimon's Lebensgeschichte, 2 vols., Karl Philipp Moritz ed. (Berlin: Vieweg, I792) (repr. Gesammelte Werke, vol. I, Valerio Verra ed. [Hildesheim: Olms, 1965]).

Versuch über die Transcendentalphilosophie mit einem Anhang über die symbolische Erkenntniß und Anmerkungen (Berlin: Voß, I790) (repr. Valerio Verra ed. Gesammelte Werke, vol. 2, Valerio Verra ed. [Hildesheim: Olms, I965]; Versuch über die Transzendentalphilosophie, Florian Ehrensperger ed. [Hamburg: Meiner, 2004]; Essay on Transcendental Philosophy, Nick Midgley ed. and transl. [London: Continuum, 2010]).

Meier, Georg Friedrich, Allgemeine practische Weltweisheit (Halle: Hemmerde, I764).

Anfangsgründe aller schönen Wissenschaften, 3 vols. (Halle: Hemmerde, I748-50).

Auszug aus der Vernunftlehre (Halle: Gebauer, I752).

Betrachtungen über die Schrancken der menschlichen Erkentnis (Halle: Hemmerde, I755).

Beweis daß die menschliche Seele ewig lebt (Halle: Hemmerde, I75 I; 2nd edn. I754).

Beweiß: daß keine Materie denken könne (Halle: Hemmerde, I742). 
Beweis der vorherbestimmten Uebereinstimmung (Halle: Hemmerde, I743).

Gedancken von dem Zustande der Seele nach dem Tode (Halle: Hemmerde, I746).

Gedancken von Gespenstern (Halle: Hemmerde, I747).

Gedancken von Schertzen (Halle: Hemmerde, I744).

Gründliche Anweisung, wie jemand ein neumodischer Weltweiser werden könne in einem Sendschreiben an einen jungen Menschen (Frankfurt and Leipzig, I745).

Metaphysik, 4 vols. (Halle: Gebauer, I75 5-7)

Philosophische Sittenlehre, 5 vols. (Halle: Hemmerde, I753-6I).

Vernunftlehre (Halle: Gebauer, I752).

Meiners, Christoph, Grundriß der Seelenlehre (Lemgo: Meyer, I786).

Mendelssohn, Moses, Ausgewählte Werke, 2 vols. Christoph Schulte, Andreas Kennecke and Grazyna Jurewicz eds. (Darmstadt: Wissenschaftliche Buchgesellschaft, 2009).

Last Works, Bruce Rosenstock transl. (Urbana, Chicago, Springfield: University of Illinois Press, 2012).

Morgenstunden oder Vorlesungen über das Daseyn Gottes (Berlin: Voß, I785). Engl. transl. Morning Hours. Lectures on God's Existence, Daniel O. Dahlstrom and Corey W. Dyck transl. (Dordrecht: Springer, 20 I I).

Ausgewählte Werke, Christoph Schulte, Andreas Kennecke and Grazyna Jurewicz eds., 2 vols. (Darmstadt: Wissenschaftliche Buchgesellschaft, 2009).

"On Evidence in Metaphysical Sciences," in Philosophical Writings, Daniel O. Dahlstrom ed. and transl. (Cambridge: Cambridge University Press, I997), pp. 25I-306.

Phaedon oder über die Unsterblichkeit der Seele in drey Gesprächen (Berlin and Stettin: Nicolai, I767).

Platner, Ernst, Anthropologie für Aerzte und Weltweise (Leipzig: Dyck, I772; repr. Hildesheim: Olms, I998).

Ed. David Hume, Gespräche über natürliche Religion. Nebst einem Gespräch über den Atheismus von Ernst Platner (Leipzig: Weygand, I78I) (translation of Hume's Dialogues Concerning Natural Religion by Karl Gottfried Schreiter).

Neue Anthropologie für Aerzte und Weltweise. Mit besonderer Rücksicht auf Physiologie, Pathologie, Moralphilosophie und Aesthetik (Leipzig: Crusius, I790).

Philosophische Aphorismen, nebst einigen Anleitungen zur philosophischen Geschichte (Leipzig: Schwickert, I776; 2nd edn., I783; 3rd edn., I793).

Ploucquet, Gottfried, Fundamenta philosophiae speculativae (1759), in Sammlung der Schriften, welche den logischen Calcul Herrn Prof. Ploucquets betreffen, August Friedrich Bök ed. (Frankfurt and Leipzig, I766), pp. I-I 4 (extracts).

Methodus calculandi in logicis, ab eodem inventa, cum commentatione de arte characteristica (1763), in Sammlung der Schriften, welche den logischen Calcul 
Herrn Prof. Ploucquets betreffen, August Friedrich Bök ed. (Frankfurt and Leipzig, I766), pp. 29-80.

Methodus tam demonstrandi directe omnes syllogismorum species, quam vitia formae detegendi, ope unius regulae (1763), in Sammlung der Schriften, welche den logischen Calcul Herrn Prof. Ploucquets betreffen, August Friedrich Bök ed. (Frankfurt and Leipzig, I766), pp. I 5-28.

Rapp, Gottlob Christian, Ueber die Untauglichkeit des Prinzips der allgemeinen und eigenen Glückseligkeit zum Grundgesetze der Sittlichkeit (Jena: Mauke, I79I).

Reinbeck, Johann Gustav, Philosophische Gedancken über die vernünfftige Seele und derselben Unsterblichkeit, Nebst einigen Anmerckungen über ein Frantzösiches Schreiben, darin behauptet werden will, daß die Materie dencke (Frankfurt and Leipzig: Marteau, I740; repr. Hildesheim: Olms, 2002).

Riem, Andreas, "Schreiben des Herrn R. an Herrn Maimon," Berlinisches Journal für Aufklärung 8/4 (letztes Stück, I790), pp. 48-5I.

Schopenhauer, Arthur, The World as Will and Representation, 2 vols., E. F. J. Payne transl. (New York: Dover, I969).

Schulz, Johann Heinrich, Versuch einer Anleitung zur Sittenlehre für alle Menschen, ohne Unterschied der Religionen, nebst einem Anhange von den Todesstrafen, 2 vols. in I (Berlin: Stahlbaum, I783).

Segner, Johann Andreas, Specimen logicae universaliter demonstratae (Jena: Croeker, I740).

Soemmerring, Samuel Thomas, Über die körperliche Verschiedenheit des Mohren vom Europäer (Mainz, I784); 2nd edn. under the title Ueber die körperliche Verschiedenheit des Negers vom Europäer (Frankfurt and Mainz: Varrentrapp Sohn und Wenner, I785).

Tetens, Johann Nikolaus, Metaphysik, Michael Sellhoff ed. (Hamburg: Meiner, 20 I6). Philosophische Versuche über die menschliche Natur und ihre Entwickelung [1777], Udo Roth and Gideon Stiening eds. (Berlin: de Gruyter, 20I4).

Ueber die allgemeine speculativische Philosophie (Bützow and Wismar: Berger und Boedner, I775).

Thümmig, Ludwig Philipp, Demonstratio immortalitatis animae ex intima eius natura deducta (Marburg: Hilliger, I72I).

Institutiones philosophiae Wolfianae (Frankfurt and Leipzig: Renger, I725).

Tittel, Gottlieb August, Erläuterungen der theoretischen und praktischen Philosophie nach Herrn Feders Ordnung, 6 vols. (Frankfurt: Garbe, 1783-6; repr. Brussels: Culture et Civilisation, 1973).

Ueber Herrn Kant's Moralreform (Frankfurt and Leipzig: Pfähler, I786; repr. Brussels: Culture et Civilisation, 1969).

Werdermann, Johann Günther Karl [also: Johann Carl Gotthelf], "Feder und Kant: Versuch zur Aufhellung einiger streitigen Punkte in den Gründen der Moralphilosophie," Berlinische Monatsschrift I (I794), pp. 309-38.

Wolff, Christian, [Anmerckungen zur Deutschen Metaphysik] Der vernünfftigen Gedancken von Gott, der Welt und der Seele des Menschen, auch allen Dingen überhaupt, Anderer Theil, bestehend in ausführlichen Anmerckungen 
[1724] (Frankfurt: Andreä und Hort, I740; repr. Hildesheim: Olms, I983, Charles A. Corr ed.).

Ausführliche Nachricht von seinen eigenen Schrifften, die er in deutscher Sprache von den verschiedenen Theilen der Welt-Weißheit heraus gegeben [1726], 2nd edn. (Frankfurt: Andreä, I733; repr. Hildesheim: Olms, I973, Hans Werner Arndt ed.).

[Deutsche Ethik] Vernünftige Gedancken von der Menschen Thun und Lassen, zu Beförderung ihrer Glückseeligkeit [I720], 4th edn. (Frankfurt and Leipzig, I733; repr. Hildesheim: Olms, I996).

[Deutsche Logik] Vernünftige Gedancken von den Kräfften des menschlichen Verstandes und ihrem richtigen Gebrauche in Erkäntniß der Wahrheit [I7I3], I4th edn. (Halle: Renger, I754).

[Deutsche Metaphysik] Vernünffige Gedancken von Gott, der Welt und der Seele des Menschen, auch allen Dingen überhaupt [I7I9], I I th edn. (Halle: Renger, I75I; repr. Hildesheim: Olms, I983, Charles A. Corr ed.).

Discursus praeliminaris de philosophia in genere. Einleitende Abhandlung über Philosophie im allgemeinen [I728], Günter Gawlick and Lothar Kreimendahl eds. and transl. (Stuttgart-Bad Cannstatt: Frommann-Holzboog, I996).

Nöthige Zugabe zu den Anmerkungen über Herrn D. Buddens Bedencken von der Wolffischen Philosophie auf Veranlassung der Buddischen Antwort heraus gegeben (Frankfurt: Andreä, I724; reprinted with same pagination in Schutzschriften gegen Johann Franz Budde, Hildesheim: Olms, I 980).

Philosophia practica universalis, methodo scientifica pertractata, 2 vols. (Frankfurt and Leipzig: Renger, I738-39; repr. Hildesheim: Olms, I97I-9).

Psychologia empirica, methodo scientifica pertractata [1732], 2nd edn. (Frankfurt and Leipzig: Renger, I738; repr. Hildesheim: Olms, I968, Jean Ėcole ed.).

Psychologia rationalis, methodo scientifica pertractata (Frankfurt and Leipzig: Renger, I734; repr. Hildesheim: Olms, I994, Jean Ècole ed.).

Zedler, Johann Heinrich (ed.), Grosses vollständiges Universal-Lexicon aller Wissenschaften und Künste, 64+4 vols. (Halle and Leipzig: Zedler, I73 I-54).

(ed.), art. "Demonstration," in Grosses vollständiges Universal-Lexicon aller Wissenschaften und Künste, vol. VII, (Halle and Leipzig: Zedler, I73 I-54), col. 535-9.

Zimmermann, Eberhard August Wilhelm von, Geographische Geschichte des Menschen, und der allgemein verbreiteten vierfüßigen Thiere, 3 vols. (Leipzig: Weygand, I778-83).

\section{Secondary Sources}

Abela, Paul, Kant's Empirical Realism (Oxford: Clarendon Press, 2002).

"Putnam and Kant on Realism," Idealistic Studies 26/I (I996), pp. 45-55.

Adickes, Erich, Kant's Systematik als systembildender Factor (Berlin: Mayer \& Müller, I 887).

Allais, Lucy, "Kant's Transcendental Idealism and Contemporary Anti-Realism," International Journal of Philosophical Studies I I/4 (2003), pp. 369-92. 
Albrecht, Michael, Eklektik. Eine Begriffsgeschichte mit Hinweisen auf die Philosophie- und Wissenschaftsgeschichte (Stuttgart-Bad Cannstatt: Frommann-Holzboog, 1994).

"Johann Georg Heinrich Feder," in Grundriss der Geschichte der Philosophie: Die Philosophie des I8. Jahrhunderts, vol. V, Helmut Holzhey and Vilem Mudroch eds. (Basel: Schwabe, 2014), pp. 249-55.

Allison, Henry E., Kant's Groundwork for the Metaphysics of Morals. A Commentary (Oxford: Oxford University Press, 20 I I).

Lessing and the Enlightenment: His Philosophy of Religion and Its Relation to Eighteenth-Century Thought (Ann Arbor: University of Michigan Press, I966).

Ameriks, Karl, Kant's Theory of Mind: An Analysis of the Paralogisms of Pure Reason, 2nd edn. (Oxford: Clarendon Press, 200o).

Anstey, Peter R. and Alberto Vanzo, "Early Modern Experimental Philosophy," in A Companion to Experimental Philosophy, Justin M. Sytsma and Wesley Buckwalter eds. (Malden, MA: Blackwell, 2016), pp. 87-102.

Arnoldt, Emil, Gesammelte Schriften, io vols., Otto Schöndörffer ed. (Berlin: Cassirer, I906-II).

Bacin, Stefano, Il senso dell'etica. Kant e la costruzione di una teoria morale (Bologna and Napoli: Il Mulino, 2006).

"Kant's Criticisms of Rationalist and Voluntarist Accounts of the Principle of Morality," in The Emergence of Autonomy in Kant's Moral Philosophy, Stefano Bacin and Oliver Sensen eds. (Cambridge: Cambridge University Press, forthcoming).

"Kant's Lectures on Ethics and Baumgarten's Moral Philosophy," in Kant's Lectures on Ethics: A Critical Guide, Lara Denis and Oliver Sensen eds. (Cambridge: Cambridge University Press, 2015), pp. I 5-33.

Barnouw, Jeffrey, "The Philosophical Achievement and Historical Significance of Johann Nicolas Tetens," Studies in Eighteenth-Century Culture 9 (1979), pp. $30 \mathrm{I}-35$.

Baumann, Julius, Wolffsche Begriffsbestimmungen: Ein Hilfsbüchlein beim Studium Kants (Leipzig: Dürr'schen Buchhandlung, I9I0).

Beck, Lewis White, Early German Philosophy: Kant and His Predecessors (Cambridge, MA: Harvard University Press, 1969).

Beiser, Frederick, Diotima's Children: German Aesthetic Rationalism from Leibniz to Lessing (Oxford University Press, 2009)

The Fate of Reason. German Philosophy from Kant to Fichte (Cambridge, MA: Harvard University Press, 1987).

Beiser, Frederick and Brandon, Look eds., The Oxford Handbook of Eighteenth Century German Philosophy (Oxford: Oxford University Press, forthcoming).

Bennett, Jonathan, Kant's Dialectic (Cambridge: Cambridge University Press, I974).

Bernasconi, Robert, "Kant and Blumenbach's Polyps. A Neglected Chapter in the History of the Concept of Race," in The German Invention of Race, Sara Eigen and Mark Larrimore eds. (Albany: SUNY Press, 2006). 
Bird, Graham, The Revolutionary Kant. A Commentary on the "Critique of Pure Reason" (Chicago: Open Court, 2006).

Brandt, Reinhard, Die Urteilstafel: Kritik der reinen Vernunft, A67-76; B92-IoI (Hamburg: Meiner, I99I).

"Feder und Kant," Kant-Studien 80/I-4 (I989), pp. 249-64.

Die Urteilstafel: Kritik der reinen Vernunft, A67-76; B92-IoI (Hamburg: Meiner, I991).

Breidert, Wolfgang, "Leonhard Euler and Philosophy," in Leonhard Euler: Life, Work and Legacy, Robert E. Bradley and C. Edward Sandifer eds. (Amsterdam: Elsevier, 2007), pp. 97-I09.

Brown, Curtis, "Internal Realism: Transcendental Idealism?" Midwest Studies in Philosophy I 2 (I988), pp. I45-55.

Buchenau, Stefanie, The Founding of Aesthetics in the German Enlightenment: The Art of Invention and the Invention of Art (Cambridge: Cambridge University Press, 2013).

Campo, Mariano, Cristiano Wolff e il razionalismo precritico (Milano: Vita e Pensiero, I939; repr. Hildesheim: Olms, I980).

La genesi del criticismo kantiano (Varese: Magenta, I953).

Cristiano Wolffe il razionalismo precritico (Milano: Vita e Pensiero, I939; repr. Hildesheim: Olms, I980).

Capozzi, Mirella and Gino Roncaglia, "Logic and Philosophy of Logic from Humanism to Kant," in The Development of Modern Logic, Leila Haaparanta ed. (Oxford: Oxford University Press, 2009), pp. 78-I 58.

Carboncini, Sonia, "Christian August Crusius und die Leibniz-Wolffische Philosophie," Studia Leibnitiana Supplementa 26 (I986): Beiträge zur Wirkungs- und Rezeptionsgeschichte von Gottfried Wilhelm Leibniz, Albert Heinekamp ed., pp. I Io-25.

"Die thomasianisch-pietistische Tradition und ihre Fortsetzung durch Christian August Crusius," in Christian Thomasius, I655-I728: Interpretationen zu Werk und Wirkung, Werner Schneiders ed. (Hamburg: Meiner, I989), pp. 287-304.

Carl, Wolfgang, Der schweigende Kant. Die Entwürfe zu einer Deduktion der Kategorien vor I78I (Göttingen: Vandenhoeck \& Ruprecht, I989).

Cassirer, Ernst, Das Erkenntnisproblem in der Philosophie und Wissenschaft der neueren Zeit, 4 vols. (Berlin: Cassirer I 906-57; vol. IV Stuttgart: Kohlhammer).

Cataldi Madonna, Luigi, Christian Wolff und das System des klassischen Rationalismus (Hildesheim: Olms, 200I).

Chance, Brian, "Kant and the Discipline of Reason," European Journal of Philosophy 23/I (2015), pp. 87-I IO.

"Pure Understanding, the Categories, and Kant's Critique of Wolff," in Freedom and Spontaneity in Kant, Kate Moran ed. (Cambridge: Cambridge University Press, forthcoming).

Ciafardone, Raffaele, "Über das Primat der praktischen Vernunft vor der theoretischen bei Thomasius und Crusius mit Beziehung auf Kant," Studia Leibnitiana I4/I (I982), pp. I27-35. 
Clark, Andy J., "Why Kant Couldn't Be an Anti-Realist," Analysis 45/I (I985), pp. 6I-3.

Conrad, Elfriede, Kants Logikvorlesungen als neuer Schlüssel zur Architektonik der Kritik der reinen Vernunft (Stuttgart-Bad Cannstatt: Frommann-Holzboog, 1994).

Cramer, Konrad, Nicht-reine synthetische Urteile a priori (Heidelberg: Carl Winter Verlag, I985).

Dicker, Georges, Kant's Theory of Knowledge: An Analytical Introduction (Oxford: Oxford University Press, 2004).

Dummett, Michael, "Realism," in id., Truth and Other Enigmas (London: Duckworth, I978), pp. I45-65.

Dunlop, Katherine, "Why Euclid's Geometry Brooked no Doubt: J. H. Lambert on Certainty and the Existence of Models," Synthese I67/I (2010), pp. 33-65.

Dyck, Corey W., "Beyond the Paralogisms: Kant on the Immortality of the Soul in the Metaphysics Lecture Notes," in Reading Kant's Lectures, Robert C. Clewis ed. (Berlin: de Gruyter, 20 I 5), pp. I I 5-34.

Kant and Rational Psychology (Oxford: Oxford University Press, 2014).

"Tetens as a Reader of Kant's Inaugural Dissertation," in Akten des I2. Internationalen Kant-Kongresses "Natur und Freiheit" in Wien vom 2I.-25. September 20I5, Violetta L. Waibel and Margit Ruffing eds. (Berlin: de Gruyter, forthcoming).

“Turning the Game against the Idealist: Mendelssohn's Refutation of Idealism in the Morgenstunden and Kant's Replies," in Moses Mendelssohn's Metaphysics and Aesthetics, Reinier Munk ed. (Dordrecht: Springer, 20 I I), pp. I 59-82.

École, Jean, "Des rapports de l'expérience et de la raison dans l'analyse de l'âme ou la 'Psychologia empirica' de Christian Wolff," Giornale di metafisica 2 I (1966), pp. 589-6I7; repr. in id., Introduction à l'opus metaphysicum de Christian Wolff (Paris: Vrin, I985), pp. 49-77.

Elkana, Yehuda, "Scientific and Metaphysical Problems: Euler and Kant," in Methodological and Historical Essays in the Natural and Social Sciences, Robert S. Cohen and Marx W. Wartofsky eds. (Dordrecht: Reidel, I974), pp. 277-305.

Erdmann, Benno, Kant's Kriticismus in der ersten und in der zweiten Auflage der Kritik der reinen Vernunft. Eine historische Untersuchung (Leipzig: Voss, I 878).

Martin Knutzen und seine Zeit. Ein Beitrag zur Geschichte der Wolfischen Schule und insbesondere zur Entwicklungsgeschichte Kants (Leipzig: Voss, I 876).

Euler, Werner, "Ernst Platners medizinische Anthropologie in der Kritik von Marcus Herz und Immanuel Kant," Aufklärung i9 (2007), pp. 2 I-68.

Fellmann, Emil A., "Leonhard Euler - Ein Essay über Leben und Werk," in Leonhard Euler 1707-1783: Beiträge zu Leben und Werk, Emil A. Fellmann ed. (Basel: Birkhäuser, I983) pp. I3-98.

Finster, Reinhard, "Zur Kritik von Christian August Crusius an der Theorie der einfachen Substanzen bei Leibniz und Wolff," Studia Leibnitiana I8/I (1986), pp. 72-82.

Fischer, Kuno, Immanuel Kant und seine Lehre. Erster Theil. Entstehung und Grundlegung der kritischen Philosophie, 3rd edn. (München: Bassermann, I 882) (vol. III of Geschichte der neuern Philosophie). 
Fonnesu, Luca, "Kant on Moral Certainty," in Kant und die Aufklärung: Akten der Kant-Tagung in Sulmona, 24.-28. März 20I0, Luigi Cataldi Madonna and Paola Rumore eds. (Hildesheim: Olms, 20I I), pp. I 83-204.

Frank, Manfred, Selbstgefühl (Frankfurt/Main: Suhrkamp, 2002).

Franks, Paul, All or Nothing: Systematicty, Transcendental Arguments, and Skepticism in German Idealism (Cambridge, MA: Harvard University Press, 2005).

Friedman, Michael, Kant and the Exact Sciences (Cambridge, MA: Harvard University Press, I992).

Fugate, Courtney and John Hymers eds., Baumgarten and Kant on Metaphysics (Oxford: Oxford University Press, forthcoming).

Garber, Daniel and Béatrice Longuenesse, Kant and the Early Moderns (Princeton, NJ: Princeton University Press, 2008).

Gasking, Elizabeth, Investigations into Generation I65I-I828 (London: Hutchinsons \& Co., I967).

Gawlick, Günter and Lothar Kreimendahl, Hume in der deutschen Aufklärung (Stuttgart-Bad Cannstatt: Frommann-Holzboog, 1987).

Gawlick, Günter, "G. F. Meiers Stellung in der Religionsphilosophie der deutschen Aufklärung" in Zentren der Aufklärung I: Halle, Aufklärung und Pietismus, Norbert Hinske ed. (Heidelberg: Verlag Lambert Schneider, I989), pp. I 57-76. Gelfert, Axel, "Kant and the Enlightenment's Contribution to Social Epistemology," Episteme 7/I (2010), pp. 79-99.

Gigerenzer, Gerd, Gut feelings: The Intelligence of the Unconscious (New York: Viking, 2007).

Griffing, Harold, "J. H. Lambert: A Study in the Development of the Critical Philosophy," The Philosophical Review 2/I (I 893), pp. 54-62.

Guyer, Paul, A History of Modern Aesthetics, Volume I: The Eighteenth Century (Cambridge: Cambridge University Press, 20I4).

(ed.), The Cambridge Companion to Kant and Modern Philosophy (Cambridge Cambridge University Press, 2006)

"From a Practical Point of View. Kant's Conception of a Postulate of Pure Practical Reason," in id., Kant on Freedom, Law, and Happiness (Cambridge: Cambridge University Press, 2000), pp. 333-7I.

"Introduction," in The Cambridge Companion to Kant's Critique of Pure Reason, Paul Guyer ed. (Cambridge: Cambridge University Press, 20Io), pp. I-I8. Kant and the Claims of Knowledge (Cambridge: Cambridge University Press, I987).

"Space, Time, and the Categories: The Project of the Transcendental Deduction," in Idealismus als Theorie der Repräsentation, Ralph Schumacher and Oliver R. Scholz eds. (Paderborn: Mentis, 2001), pp. 31 3-38.

Guyer, Paul and Allen Wood, "Introduction" in Immanuel Kant, Critique of Pure Reason, Paul Guyer and Allen Wood eds. and transl. (Cambridge: Cambridge University Press, 1998).

Hacking, Ian, Representing and Intervening (Cambridge: Cambridge University Press, 1983). 
Hamilton, William, Lectures on Metaphysics and Logics, 4 vols. (Edinburgh: William Blackwood and Sons, I860).

Hanna, Robert, "Kant, Truth, and Human Nature," British Journal for the History of Philosophy 8/2 (2000), pp. 225-50.

Hatfield, Gary, The Natural and the Normative: Theories of Spatial Perception from Kant to Helmholtz (Cambridge, MA: MIT Press, I990).

Hauser, Christian, Selbstbewußtsein und personale Identität. Positionen und Aporien ihrer vorkantischen Geschichte. Locke, Leibniz, Hume und Tetens (StuttgartBad Cannstatt: Fromman-Holzboog, I994).

Heidemann, Dietmar H., Kant und das Problem des metaphysischen Idealismus (Berlin: de Gruyter, 1998).

Heimsoeth, Heinz, Metaphysik und Kritik bei Chr. Aug. Crusius (Berlin: Deutsche Verlagsgesellschaft, 1926); repr. in id., Studien zur Philosophie Immanuel Kants (Kölner Universitäts-Verlag, I956), pp. I25-88.

Helbig, Daniela and Dalia Nassar, "The Metaphor of Epigenesis: Kant, Blumenbach and Herder," Studies in History and Philosophy of Science Part A 55 (2016), pp. 98-107.

Henrich, Dieter, "Die Deduktion des Sittengesetzes. Über die Gründe der Dunkelheit des letzten Abschnittes von Kants 'Grundlegung zur Metaphysik der Sitten," in Denken im Schatten des Nibilismus. Festschrift für Wilhelm Weischedel zum 70. Geburtstag, Alexander Schwan ed. (Darmstadt: Wissenschaftliche Buchgesellschaft, I975), pp. 55-I I 2.

"Kant's Notion of a Deduction and the Methodological Background of the First Critique" in Kant's Transcendental Deductions, Eckart Förster ed. (Palo Alto, CA: Stanford University Press, I988), pp. 29-46.

"Über Kants früheste Ethik. Versuch einer Rekonstruktion," Kant-Studien 54/ I-4 (I963), pp. 404-3I.

Heßbrüggen-Walter, Stefan, Die Seele und ihre Vermögen. Kants Metaphysik des Mentalen in der "Kritik der reinen Vernunft" (Paderborn: Mentis, 2004).

"Kant, Tetens und die Grundkraft der Seele," in Kant und die Berliner Aufklärung. Akten des IX. Internationalen Kant-Kongresses, vol. IV, Volker Gerhardt, Rolf-Peter Horstmann and Ralph Schumacher eds. (Berlin: de Gruyter, 200I), pp. 368-74.

Holzhey, Helmut and Vilem Mudroch eds., Grundriss der Geschichte der Philosophie. Die Philosophie des I8. Jahrhunderts. Band 5: Heiliges Römisches Reich deutscher Nation, Schweiz, Nord- und Osteuropa (Basel: Schwabe, 20 I4).

Hinske, Norbert (ed.), Ich handle mit Vernunft. Moses Mendelssohn und die europäische Aufklärung (Hamburg: Meiner, I98I).

(ed.), Kant und die Aufklärung (vol. 7/I of Aufklärung, 1992).

Hinske, Norbert and Claudio Cesa (eds.), Kant und sein Jahrhundert. Gedenkschrift für Giorgio Tonelli (Frankfurt/Main: Lang, I993).

Hruschka, Joachim, "The Greatest Happiness Principle and Other Early German Anticipations of Utilitarian Theory," Utilitas 3/2 (199I), pp. I65-77.

Kanzian, Christian, "Kant und Crusius I763," Kant-Studien 84/4 (1993), pp. 399-407. 
Kitcher, Patricia, “Analyzing Apperception (Gewahrnehmen)," in Johann Nikolaus Tetens (1736-I807). Philosophie in der Tradition des europäischen Empirismus, Gideon Stiening and Udo Thiel eds. (Berlin: de Gruyter, 2014), pp. I03-32.

Kant's Thinker (Oxford: Oxford University Press, 20 I I).

Kant's Transcendental Psychology (Oxford: Oxford University Press, I990).

Klatt, Norbert, "Johann Friedrich Blumenbach als ungenannter Gegner in Georg Forsters Streit mit Immanuel Kant über den Rassenbegriff,” Kleine Beiträge zur Blumenbach-Forschung 3 (2010), pp. 78-I 2 I.

Klemme, Heiner F., "“als ob er frei wäre'. Kants Rezension von Johann Heinrich Schulz' Versuch einer Anleitung zur Sittenlehre für alle Menschen," in Critica y Metafísica. Homenaje a Mario Caimi, Claudia Jáuregui, Fernando Moledo, Hernán Pringe and Marcos Thisted eds. (Hildesheim: Olms, 2015), pp. 200-2 I I.

"Freiheit oder Fatalismus? Kants positive und negative Deduktion der Idee der Freiheit in der Grundlegung (und seine Kritik an Christian Garves Antithetik von Freiheit und Notwendigkeit)," in Deduktion oder Faktum? Kants Rechtfertigung des Sittengesetzes im dritten Abschnitt der "Grundlegung", Heiko Puls ed. (Berlin: de Gruyter, 20I4), pp. 6I-Io3.

"Johann Georg Sulzers 'vermischte Sittenlehre'. Ein Beitrag zur Vorgeschichte und Problemstellung von Kants Grundlegung zur Metaphysik der Sitten," in Johann Georg Sulzer (I720-I779). Aufklärung zwischen Christian Wolff und David Hume, Frank Grunert and Gideon Stiening eds. (Berlin: de Gruyter, 20II), pp. 309-22.

Kants Philosophie des Subjekts. Systematische und entwicklungsgeschichtliche Untersuchungen zum Verhältnis von Selbstbewußstein und Selbsterkenntnis (Hamburg: Meiner, 1996).

"La pratique de la moralité. Le lien entre théorie et pratique dans la philosophie pratique kantienne," Revue germanique internationale 6 (I996), pp. I39-57.

Klemme, Heiner F. and Manfred Kuehn (eds.), The Bloomsbury Dictionary of Eighteenth Century German Philosophers, 2nd edn. (London: Bloomsbury, 2015).

Kosenina, Alexander, Ernst Platners Anthropologie und Philosophie (Würzburg: Königshausen und Neumann, I989).

Kraft, Bernd and Dieter Schönecker, "Einleitung," in Immanuel Kant, Grundlegung zur Metaphysik der Sitten, Bernd Kraft and Dieter Schönecker eds. (Hamburg: Meiner, I999).

Krieger, Martin, Geist, Welt und Gott bei Christian August Crusius: erkenntnistheoretisch-psychologische, kosmologische und religionsphilosophische Perspektiven im Kontrast zum Wolffschen System (Würzburg: Königshausen und Neumann, I993).

Kroke, Claudia, Johann Friedrich Blumenbach. Bibliographie seiner Schriften. Unter Mitarbeit von Wolfgang Böker und Reimer Eck (Göttingen: Universitätsverlag, 20Io) (online www.blumenbach-online.de/fileadmin/ wikiuser/Daten_Digitalisierung/Bibliographie/Bibliographie.html). 
Krouglov, Alexei N., "Der Begriff 'transzendental' bei J. N. Tetens. Historischer Kontext und Hintergründe," Aufklärung I7 (2005), pp. 35-75.

"Tetens und die Deduktion der Kategorien bei Kant," Kant-Studien Io4/4, (2013), pp. 466-89.

Kuehn, Manfred, "Hume and Tetens," Hume Studies I 5/2 (I989), pp. 365-76. "The German Aufklärung and British Philosophy," in British Philosophy and the Age of Enlightenment, Stuart Brown ed. (London: Routledge, I996), pp. 309-3 I.

Kant. A Biography (Cambridge: Cambridge University Press, 200 I).

Scottish Common Sense in Germany, I768-I800 (Kingston and Montreal: McGill-Queen's University Press, I987).

"Skepticism: Philosophical Disease or Cure?" in The Skeptical Tradition around I800, Richard H. Popkin and Johan van der Zande eds. (Dordrecht: Kluver, I998), pp. 8 I-IoO.

Langton, Rae, "Duty and Desolation," Philosophy 67/2 (I992), pp. 48 I-505.

Laywine, Alison, "Kant and Lambert on Geometrical Postulates in the Reform of Metaphysics," in Discourse on a New Method: Reinvigorating the Marriage of History and Philosophy of Science, Mary Domski and Michael Dickson eds. (Chicago: Open Court, 2010), pp. I I 3-33.

Kant's Early Metaphysics and the Origins of the Critical Philosophy (Atascadero, CA: Ridgeview, I993).

Lennon, Thomas M. and Robert J. Stainton (eds.), The Achilles of Rationalist Psychology (Dordrecht: Springer, 2008).

Longuenesse, Béatrice, "The Divisions of Transcendental Logic and the Leading Thread," in Immanuel Kant: Kritik der reinen Vernunft, Georg Mohr and Marcus Willaschek eds. (Berlin: Akademie Verlag, I998), pp. I 3 I-I 58.

Kant and the Capacity to Judge (Princeton, NJ: Princeton University Press, I998).

"Kant on A Priori Concepts: the Metaphysical Deduction of the Categories," in The Cambridge Companion to Kant and Modern Philosophy, Paul Guyer ed. (Cambridge: Cambridge University Press, 2006), pp. I 26-I68.

Lu-Adler, Huaping, Kant's Conception of Logical Extension and Its Implications, unpublished PhD thesis, University of California, Davis (2012).

"The Objects and the Formal Truth of Kantian Analytic Judgments," History of Philosophy Quarterly 30/2 (2013), pp. I77-93.

Mahon, James Edwin, "Kant and Maria Von Herbert: Reticence vs. Deception," Philosophy 8I/3 (2006), pp. 4I7-44.

Marcolungo, Ferdinando (ed.), Christian Wolff tra psicologia empirica e psicologia razionale (Hildesheim: Olms, 2007).

Marciszewski, Witold and Roman Murawski, Mechanization of Reasoning in a Historical Perspective (Amsterdam: Rodopi, I995).

Marino, Luigi, Praeceptores Germaniae. Göttingen I770-I820 (Göttingen, Vandenhoeck \& Ruprecht, I995).

Marquardt, Anton, Kant und Crusius. Ein Beitrag zum richtigen Verständnis der crusianischen Philosophie (Kiel: Lipsius \& Tischer, I 885). 
McLaughlin, Peter, "Blumenbach und der Bildungstrieb: Zum Verhältnis von epigenetischer Embryologie und typologischem Artbegriff," Medizinhistorisches Journal I7/4 (I982), pp. 357-72.

Mensch, Jennifer, "From Crooked Wood to Moral Agent: Connecting Anthropology and Ethics in Kant," Estudos Kantianos 2/I (2014), I85-204.

"Kant and the Problem of Idealism: On the Significance of the Göttingen Review," The Southern Journal of Philosophy 44/2 (2006), pp. 297-3 I7.

"Kant on Truth," Idealistic Studies 34/2 (2004), pp. I63-72.

Kant's Organicism. Epigenesis and the Development of Critical Philosophy (Chicago: University of Chicago Press, 2013).

Messina, James, "Kant on the Unity of Space and the Synthetic Unity of Apperception," Kant-Studien I05/I (2014), pp. 5-40.

Mijuskovic, Ben Lazare, The Achilles of Rationalist Arguments. The Simplicity, Unity, and Identity of Thought and Soul from the Cambridge Platonists to Kant (The Hague: Nijhoff, I974).

Mikkelsen, Jon (ed. and transl.), Kant and the Concept of Race. Late EighteenthCentury Writings (Albany: SUNY Press, 2013).

Moran, Dermot, "Hilary Putnam and Immanuel Kant: Two 'Internal Realists'?" Synthese I23/I (2000), pp. 65-I04.

Mosser, Kurt, Necessity \& Possibility. The Logical Strategy of Kant's "Critique of Pure Reason" (Washington, DC: Catholic University of America Press, 2008).

Motta, Giuseppe, Die Postulate des empirischen Denkens überhaupt (Berlin: de Gruyter, 2012).

Munk, Reinier, "'What Is the Bond?' The Discussion of Mendelssohn and Kant I785-I787," in Moses Mendelssohn's Metaphysics and Aesthetics, Reinier Munk ed. (Dordrecht: Springer, 20I I), pp. I83-202.

Naschert, Guido, "Johann Georg Heinrich Feder (I740-I82 I)," Aufklärung 24 (2012), pp. 345-48.

Naschert, Guido and Gideon Stiening (eds.), Ernst Platner (I744-I8I8). Konstellationen der Aufklärung zwischen Philosophie, Medizin und Anthropologie (Aufklärung I9 [2007]).

Nisbet, Hugh Barr, Gotthold Ephraim Lessing. His Life, Works, and Thought (Oxford: Oxford University Press, 2013).

Nowitzki, Hans-Peter, "Curriculum Vitae. Fundstücke und Nachträge zur Biographie Ernst Platners," Aufklärung i9 (2007), pp. 343-78.

Der wohltemperierte Mensch. Aufklärungsanthropologien im Widerstreit (Berlin: de Gruyter, 2003).

"Platner und die Wolffsche Philosophietradition," Aufklärung I9 (2007), pp. 69-I04.

Pasternack, Lawrence, "The Development and Scope of Kantian Belief: The Highest Good, The Practical Postulates and the Fact of Reason," KantStudien I02/3 (201 I), pp. 290-3 I 5 .

Perin, Adriano, "The Proof of the Principle of Sufficient Reason: Wolff, Crusius and the Early Kant on the Search for a Foundation of Metaphysics," Revista Portuguesa de Filosofia 71/2-3 (2015), pp. 51 5-29. 
Perinetti, Dario, "Ways to certainty," in The Routledge Companion to Eighteenth Century Philosophy, Aaron Garrett ed. (New York: Routledge, 2014), pp. $265-93$.

Pietsch, Lutz-Henning, Topik der Kritik. Die Auseinandersetzung um die Kantische Philosophie (I78I-I788) und ihre Metaphern (Berlin: de Gruyter, 2010).

Pippin, Robert B., Kant's Theory of Form (New Haven: Yale University Press, I982).

Posada Kubissa, Luisa, "Sobre Kant, Putnam y el realismo interno," Anales del Seminario de Historia de la Filosofía 29/I (2012), pp. 173-87.

Posy, Carl J., "The Language of Appearances and Things in Themselves," Synthese 47/2 (I98I), pp. 3I3-5I.

Pozzo, Riccardo, Kant und das Problem einer Einleitung in die Logik: Ein Beitrag zur Rekonstruktion der historischen Hintergründe von Kants Logik-Kolleg (Frankfurt: Lang, 1989).

"Prejudices and Horizons: G. F. Meier's Vernunftlehre and its Relation to Kant," Journal of the History of Philosophy 43/2 (2005), pp. I 85-202.

Prantl, Carl, Geschichte der Logik im Abendlande, 4 vols. (Leipzig: Hirzel, I $855-70$ ).

Prauss, Gerold, "Zum Wahrheitsproblem bei Kant," Kant-Studien 6o/2 (I969), pp. I66-82.

Puls, Heiko, "Freiheit als Unabhängigkeit von bloß subjektiv bestimmenden Ursachen - Kants Auflösung des Zirkelverdachts im dritten Abschnitt der 'Grundlegung zur Metaphysik der Sitten'," Zeitschrift für philosophische Forschung 65/4 (201 I), pp. 534-652.

Putnam, Hillary, The Many Faces of Realism (La Salle: Open Court, 1987).

Realism with a Human Face (Cambridge, MA: Harvard University Press, 1992). Reason, Truth and History (Cambridge: Cambridge University Press, I98I).

"Sense, Nonsense, and the Senses: An Inquiry into the Powers of the Human Mind," Journal of Philosophy 91/9 (1994), pp. 445-517.

Rappard, Hans V., Psychology as Self-knowledge. The Development of the Concept of the Mind in German Rationalistic Psychology and Its Relevance Today (Assen: Van Gorcum, 1979).

Rescher, Nicholas, "Leibniz's Interpretation of his Logical Calculi," Journal of Symbolic Logic I9/I (1954), pp. I-I3.

Galen and the Syllogism (Pittsburgh: University of Pittsburgh Press, I966).

Richards, Robert J., "Kant and Blumenbach on the Bildungstrieb: A Historical Misunderstanding," Studies in the History and Philosophy of Biology and the Biomedical Sciences 3 I/I (2000), pp. I I-32.

Ricken, Friedo, "Die Postulate der reinen praktischen Vernunft," in Immanuel Kant. Kritik der praktischen Vernunft, Otfried Höffe ed. (Berlin: Akademie Verlag, 2002), pp. I87-202.

Roe, Shirley A., Matter, Life, and Generation. I8th-Century Embryology and the Haller-Wolff Debate (Cambridge: Cambridge University Press, 198I).

Roger, Jacques, The Life Sciences in Eighteenth-Century French Thought, Robert Ellrich transl., Keith R. Benson ed. (Palo Alto, CA: Stanford University Press, 1997).

Rohr, Paul, Platner und Kant (Gotha: Engelhard, I890). 
Rorty, Richard, Philosophy and the Mirror of Nature (Princeton, NJ: Princeton University Press, I979).

Rosenkoetter, Timothy, "Truth Criteria and the Very Project of a Transcendental Logic," Archiv für Geschichte der Philosophie 91/2 (2009), pp. 193-236.

Röttgers, Kurt, "J. G. H. Feder - Beitrag zu einer Verhinderungsgeschichte eines deutschen Empirismus," Kant-Studien 75/I-4 (I984), pp. 420-4I.

Roth, Udo and Gideon Stiening, "Zur Einführung," in Johann Nikolaus Tetens, Philosophische Versuche über die menschliche Natur und ihre Entwickelung, Udo Roth and Gideon Stiening eds. (Berlin: de Gruyter, 20I4), pp. ix-xxxi.

Rudolph, Oliver-Pierre and Jean-François Goubet (eds.), Die Psychologie Christian Wolff: Systematische und historische Untersuchungen (Berlin: de Gruyter, 2004).

Rumore, Paola, "Georg Friedrich Meiers Theorie der Unsterblichkeit der Seele im zeitgenössischen Kontext," in Georg Friedrich Meier (I7I8-I777). Philosophie als "wahre Weltweisheit", Gideon Stiening and Frank Grunert eds. (Berlin: de Gruyter, 2015), pp. I63-86.

"Kant's Understanding of the Enlightenment with Reference to his Refutation of Materialism," Con-Textos Kantianos. International Journal of Philosophy I (2014), pp. 80-95.

Materia cogitans. L'Aufklärung di fronte al materialismo (Hildesheim: Olms, 2013).

"Meier, Kant e il materialismo psicologico," in Kant und die Aufklärung, Luigi Cataldi Madonna and Paola Rumore eds. (Hildesheim: Olms, 20II), pp. 329-55.

"Un wolffiano diffidente: Georg Friedrich Meier e la sua dottrina dei pregiudizi," in Georg Friedrich Meier, Contributi alla dottrina dei pregiudizi del genere umano / Beyträge zu der Lehre von den Vorurtheilen des menschlichen Geschlechts, Heinrich P. Delfosse, Norbert Hinske and Paola Rumore eds. (Pisa: ETS, 2005), pp. v-xxxvi.

Sassen, Brigitte (ed.), Kant's Early Critics: The Empiricist Critique of the Theoretical Philosophy (Cambridge: Cambridge University Press, 2000).

Schmucker, Josef, Die Ursprünge der Ethik Kants in seinen vorkritischen Schriften und Reflektionen (Meisenheim: Hain, I96I).

Schönfeld, Martin, The Philosophy of the Young Kant. The Precritical Project (Oxford: Oxford University Press, 200o).

Schröpfer, Horst, Kants Weg in die Öffentlichkeit. Christian Gottfried Schütz als Wegbereiter der kritischen Philosophie (Stuttgart-Bad Cannstatt: FrommannHolzboog, 2003).

Schwaiger, Clemens, "Christian Wolffs Philosophia practica universalis. Zu ursprünglichem Gehalt und späterer Gestalt einer neuen Grundlagendisziplin," in Macht und Bescheidenheit der Vernunft. Beiträge zur Philosophie Christian Wolff, Luigi Cataldi Madonna ed. (Hildesheim: Olms, 2005), pp. 219-33.

Kategorische und andere Imperative. Zur Entwicklung von Kants praktischer Philosophie bis 1785 (Stuttgart-Bad Cannstatt, Frommann-Holzboog, I999). 


\section{Bibliography}

"Christian Wolffs Philosophia practica universalis. Zu ursprünglichem Gehalt und späterer Gestalt einer neuen Grundlagendisziplin," in Macht und Bescheidenheit der Vernunft. Beiträge zur Philosophie Christian Wolff, Luigi Cataldi Madonna ed. (Hildesheim: Olms, 2005), pp. 219-33.

Seidel, Arthur, Tetens' Einfluß auf die Philosophie Kants (Würzburg: Triltsch, 1932). Seligkowitz, Benzian, "Ernst Platner's wissenschaftliche Stellung zu Kant in Erkenntnistheorie und Moralphilosophie," Vierteljahresschrift für wissenschaftliche Philosophie I6 (1892), pp. 76-103, I72-91.

Sellars, Wilfrid, Science and Metaphysics. Variations on Kantian Themes (New York: Humanities Press, I968).

Sellhoff, Michael, "Einleitung," in Johann Nicolaus Tetens: Metaphysik, Michael Sellhoff ed. (Hamburg: Meiner, 20I6), pp. XI-CXXVIII.

Sher, Gila, "On the Possibility of a Substantive Theory of Truth," Synthese I I 7/ I (1999), pp. 133-72.

Sikka, Sonia, Herder on Humanity and Cultural Difference (Cambridge: Cambridge University Press, 20 I I).

Sloan, Phillip, "Buffon, German Biology, and the Historical Interpretation of Biological Species," British Journal for the History of Science I2/2 (1979), pp. I09-53.

Smith, Justin E. H. (ed.), The Problem of Animal Generation in Early Modern Philosophy (Cambridge: Cambridge University Press, 2006).

Sommer, Robert, Grundzüge einer Geschichte der deutschen Psychologie und Aesthetik von Wolff-Baumgarten bis Kant-Schiller (Würzburg: Stahel, I892).

Stapleford, Scott, "Reid, Tetens, and Kant on the External World," Idealistic Studies 37/2 (2007), pp. 87-104.

Stevenson, Leslie and Ralph Walker, "Empirical Realism and Transcendental Anti-Realism," Proceedings of the Aristotelian Society, suppl. vol. 57, pp. I3 I-77.

Stiening, Gideon, "Platners Aufklärung. Das Problem der eingeborenen Ideen zwischen Anthropologie, Erkenntnistheorie und Metaphysik," Aufklärung I9 (2007), pp. I05-I 38.

Stiening, Gideon and Udo Thiel (eds.), Johann Nikolaus Tetens (1736-1807). Philosophie in der Tradition des europäischen Empirismus (Berlin: de Gruyter, 20I4).

Strawson, Peter F., The Bounds of Sense (London: Methuen, 1966).

"The Problem of Realism and the A Priori," in Kant and Contemporary Epistemology, Paolo Parrini ed. (Dordrecht: Kluwer, 1994), pp. I67-73.

Sturm, Thomas, Kant und die Wissenschaften vom Menschen (Paderborn: Mentis, 2009).

"Wahrheit," in Kant-Lexikon, vol. III, Marcus Willaschek, Jürgen Stolzenberg, Georg Mohr and Stefano Bacin eds. (Berlin: de Gruyter, 2015), pp. 2624-30.

Tafani, Daniela, Virtù e felicità in Kant (Florence: Olschki, 2006).

Thiel, Udo, "Das 'Gefühl Ich'. Ernst Platner zwischen Empirischer Psychologie und Transzendentalphilosophie," Aufklärung I9 (2007), pp. I39-6I. 
The Early Modern Subject. Self-Consciousness and Personal Identity from Descartes to Hume (Oxford: Oxford University Press, 201 I).

"Johann Georg Heinrich Feder," in The Dictionary of Eighteenth-Century German Philosophers, vol. I, Heiner F. Klemme and Manfred Kuehn eds. (Bristol: Continuum, 2010), pp. 308-I 5.

"Unities of the Self: From Kant to Locke," Kant Yearbook 7 (2015), pp. I39-65.

"Varieties of Inner Sense. Two Pre-Kantian Theories," Archiv für Geschichte der Philosophie 79/I (I997), pp. 58-79.

"Zum Verhältnis von Gegenstandsbewußtsein und Selbstbewußtsein bei Wolff und seinen Kritikern," in Christian Wolff und die Europäische Aufklärung, vol. II, Jürgen Stolzenberg and Oliver-Pierre Rudolph eds. (Hildesheim: Olms, 2007), pp. 377-90.

"Zwischen Empirischer Psychologie und Rationaler Seelenlehre. Tetens über das Selbstgefühl," in Johann Nikolaus Tetens (1736-1807). Philosophie in der Tradition des europäischen Empirismus, Gideon Stiening and Udo Thiel eds. (Berlin: de Gruyter, 2014), pp. 89-102.

Thielke, Peter, "Rationalism, Empiricism, and Skepticism: The Curious Case of Maimon's 'Coalition-System'," in The Palgrave Handbook of German Idealism, Matthew C. Altman ed. (London: Palgrave Macmillan, 20I4), pp. 222-42.

Timerding, Heinrich Emil, "Kant und Euler," Kant-Studien 23/I-3 (I919), pp. I 8-64.

Tolley, Clinton, "The Generality of Kant's Transcendental Logic," Journal of the History of Philosophy 50/3 (2012), pp. 417-46.

Tomasoni, Francesco, "Mendelssohn's Concept of the Human Soul in Comparison with those of Meier and Kant," in Moses Mendelssohn's Metaphysics and Aesthetics, Reinier Munk ed. (Dordrecht: Springer, 20 I I), pp. I3 I-57.

Tonelli, Giorgio, "Der historische Ursprung der kantischen Termini 'Analytik' und 'Dialektik'," Archiv für Begriffsgeschichte 7 (I962), pp. I 20-39.

"Der Streit über die mathematische Methode in der ersten Hälfte des XVIII. Jahrhunderts und die Entstehung von Kants Schrift über die 'Deutlichkeit'," Archiv für Philosophie 9 (1959), pp. 243-94.

Elementi metodologici e metafisici in Kant dal I745 al I768. Saggio di sociologia della conoscenza (Torino: Edizioni di "Filosofia", 1959).

Kant's 'Critique of Pure Reason' Within the Tradition of Modern Logic, David H. Chandler ed. (Hildesheim: Olms, I994).

"Vorwort," in Christian August Crusius, Die philosophischen Hauptwerke, vol. I, Giorgio Tonelli ed., 4 vols. in 5 (vol. IV, Sonia Carboncini and Reinhard Finster eds.) (Hildesheim: Olms I964-88), pp. vii-xlv.

Uebele, Wilhelm, Johann Nicolaus Tetens nach seiner Gesamtentwicklung betrachtet, mit besonderer Berücksichtigung des Verhältnisses zu Kant (Berlin: Reuther \& Reichard, I9II).

Ueberweg, Friedrich, System der Logik und Geschichte der logischen Lehren (Bonn: Marcus, I865). 
Vaihinger, Hans, Commentar zu Kants Kritik der reinen Vernunft. Zum hundertjährigen Jubiläum derselben, 2 vols. (vol. I Stuttgart: Spemann, I 88I; vol. 2 Stuttgart, Berlin and Leipzig: Union Deutsche Verlagsgesellschaft, I 892).

Van Cleve, James, Problems from Kant (Oxford: Oxford University Press, I999).

Vanzo, Alberto, "Empiricism and Rationalism in Nineteenth-Century Histories of Philosophy," Journal of the History of Ideas 77/2 (2016), pp. 253-82.

"Kant on Empiricism and Rationalism," History of Philosophy Quarterly 30/I (2013), pp. 53-74.

"Kant on the Nominal Definition of Truth," Kant-Studien Ior/2 (2010), pp. I 47-66.

Venn, John, Symbolic Logic, 2nd edn. (London: Macmillan, I 894).

Vesper, Achim, "Zwischen Hume und Kant: Moralbegründung in Feders Untersuchungen über den menschlichen Willen," in Johann Georg Heinrich Feder. Empirismus und Popularphilosophie zwischen Wolff und Kant, HansPeter Nowitzki and Gideon Stiening eds. (Berlin: de Gruyter, forthcoming).

Vidal, Fernando, The Sciences of the Soul: The Early Modern Origins of Psychology (Chicago: University of Chicago Press, 201 I).

Vittadello, Anna Maria, "Expérience et raison dans la psychologie de Christian Wolff," Revue philosophique de Louvain 7 I/ I I (I973), pp. 488-5 I I.

Vorländer, Karl, Immanuel Kant. Der Mann und das Werk, 3 rd edn., Rudolf Malter ed. (Hamburg: Meiner, I992).

Walker, Ralph C. S., The Coherence Theory of Truth: Realism, Anti-Realism, Idealism (London: Routledge, I989).

Walsh, William H., Kant's Criticism of Metaphysics (Edinburgh: Edinburgh University Press, I975).

Warda, Arthur, Immanuel Kants Bücher (Berlin: Martin Breslauer, I922).

Warren, Daniel, "Kant's Dynamics," in Kant and the Sciences, Eric Watkins ed. (New York: Oxford University Press, 200I) pp. 93-I I6.

Watkins, Eric, "The Development of Physical Influx in Early Eighteenth-Century Germany: Gottsched, Knutzen, and Crusius," Review of Metaphysics 49/2 (I995), pp. 295-339.

"From Pre-established Harmony to Physical Influx," Perspectives on Science 6/ I-2 (1998), pp. I36-203.

Kant and the Metaphysics of Causality (Cambridge: Cambridge University Press, 2005).

Kant's "Critique of Pure Reason": Background Source Materials (Cambridge: Cambridge University Press, 2009).

Watkins, Eric and Marcus Willaschek, "Kant on Cognition and Knowledge" (unpublished manuscript).

"Kant's Account of Cognition," Journal of the History of Philosophy 55 (2017), pp. 83-I I 2 .

Waxman, Wayne, Kant and the Empiricists: Understanding Understanding (Oxford: Oxford University Press, 2005).

Kant's Anatomy of the Intelligent Mind (Oxford: Oxford University Press, 2013). 
Kant's Model of the Mind (Oxford: Oxford University Press, I99I).

Wessell, Leonard P. Jr., "G. F. Meier and the Genesis of Philosophical Theodicies of History in $18^{\text {th }}$-Century Germany," Lessing Yearbook I2 (I980), pp. 63-84.

Winter, Alois, "Seele als Problem in der Transzendentalphilosophie Kants unter besonderer Berücksichtigung des Paralogismuskapitels," in Seele. Ihre Wirklichkeit, ihr Verhältnis zum Leib und zur menschlichen Person, Klaus Kremer ed. (Leiden: Brill, I984), pp. Ioo-168.

Wolff, Michael, Die Vollständigkeit der kantischen Urteilstafel (Frankfurt am Main: Klostermann, I995).

Wolff, Robert Paul, Kant's Theory of Mental Activity (Cambridge, MA: Harvard University Press, 1963).

Wolters, Gereon, Basis und Deduktion: Studien zur Entstehung und Bedeutung der Theorie der axiomatischen Methode bei J.H. Lambert (I728-I777) (Berlin: de Gruyter, I980).

"Some Pragmatic Aspects of the Methodology of J. H. Lambert," in Change and Progress in Modern Science, Joseph C. Pitt ed. (Dordrecht: Reidel, I985), pp. I33-70.

Wood, Allen W., Kant's Moral Religion (Ithaca: Cornell University Press, I970). Wreschner, Arthur, Ernst Platners und Kants Erkenntnistheorie mit besonderer Berücksichtigung von Tetens und Aenesidemus (Halle: Heynemann, I89I).

Wunderlich, Falk, "Eine 'dritte Mittelidee von der Beschaffenheit des Seelenwesens'. Johann Nicolaus Tetens und die Annäherung von Influxus physicus und Harmonismus," in Johann Nicolaus Tetens (I736-I807) und die Tradition des europäischen Empirismus, Udo Thiel and Gideon Stiening eds. (Berlin: de Gruyter, 2014), pp. 219-49.

"Ernst Platners Auseinandersetzung mit David Hume," Aufklärung i9 (2007), pp. I63-80.

"Garve, Christian (I742-98)," in The Bloomsbury Dictionary of Eighteenth Century German Philosophers, Heiner F. Klemme and Manfred Kuehn eds. (London and New York: Bloomsbury, 20I6), pp. 246-5 I.

"Gibt es eine 'Impression des Selbst'? Humes Theorie des Geistes in der deutschen Debatte des I 8. Jahrhunderts," in David Hume nach 300 Jahren. Historische Kontexte, systematische Perspektiven, Frank Brosow and Heiner F. Klemme eds. (Münster: Mentis, 20I4), pp. 26-53.

Kant und die Bewußtseinstheorien des I8. Jahrhunderts (Berlin: de Gruyter, 2005).

Wundt, Max, Die deutsche Schulphilosophie im Zeitalter der Aufklärung (Tübingen: Mohr, I945; repr. Hildesheim: Olms, 1992).

Yolton, John W., Perceptual Acquaintance from Descartes to Reid (Minneapolis: University of Minnesota Press, I984).

Zammito, John, Kant, Herder, and the Birth of Anthropology (Chicago: University of Chicago Press, 2002).

"The Lenoir Thesis revisited: Blumenbach and Kant," Studies in History and Philosophy of Biological and Biomedical Sciences 43 (2012), pp. I20-32. 
Zantwijk, Temilo van, "Platner, Kant und der Skeptizismus," Aufklärung I9 (2007), pp. I8 I-96.

Zeller, Eduard, "Wolffs Vertreibung aus Halle. Der Kampf des Pietismus mit der Philosophie. Ein Beitrag zur deutschen Culturgeschichte," Preußische Jahrbücher Io (I 862), pp. 47-72.

Zimmerli, Walter Ch., “'Schwere Rüstung' des Dogmatismus und 'anwendbare Eklektik'. J. G. J. Feder und die Göttinger Philosophie im ausgehenden I 8. Jahrhundert," Studia Leibnitiana I 5/I (I983), pp. 58-7I. 